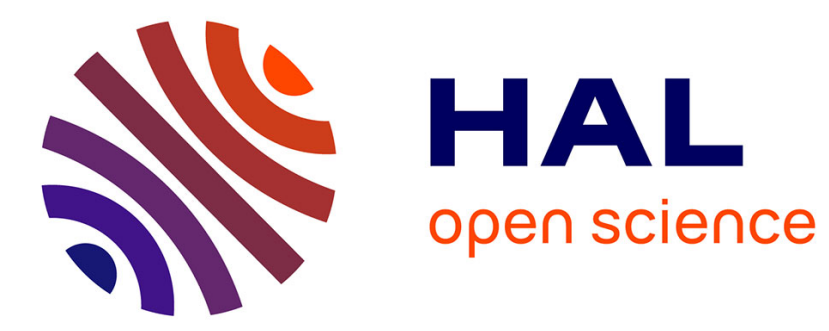

\title{
New insights on activity-related bone functional adaptations and alterations in Neolithic Liguria (northwestern Italy)
}

A. Varalli, Sébastien Villotte, I. Dori, V.S. Sparacello

\section{- To cite this version:}

A. Varalli, Sébastien Villotte, I. Dori, V.S. Sparacello. New insights on activity-related bone functional adaptations and alterations in Neolithic Liguria (northwestern Italy). Bulletins et Mémoires de la Société d'anthropologie de Paris, 2020, 10.3166/bmsap-2020-0072 . hal-03007251

\section{HAL Id: hal-03007251 \\ https://hal.science/hal-03007251}

Submitted on 16 Nov 2020

HAL is a multi-disciplinary open access archive for the deposit and dissemination of scientific research documents, whether they are published or not. The documents may come from teaching and research institutions in France or abroad, or from public or private research centers.
L'archive ouverte pluridisciplinaire $\mathbf{H A L}$, est destinée au dépôt et à la diffusion de documents scientifiques de niveau recherche, publiés ou non, émanant des établissements d'enseignement et de recherche français ou étrangers, des laboratoires publics ou privés. 
Article, reçu le 14/11/2019, accepté le 18/02/2020. 10 figures (Fig. 1, 6, 7, 8, 9 and 10 une colonne et demi, Fig. 2, 3, 4 and 5 deux colonnes), 7 tableaux, 2 annexes

Title: New insights into activity-related functional bone adaptations and alterations in Neolithic Liguria (northwestern Italy)

Titre : Nouvelles connaissances sur les adaptations et altérations fonctionnelles osseuses liées à l'activité en Ligurie néolithique (nord-ouest de l'Italie)

Authors: Varalli $\mathrm{A}^{1,2}$, Villotte $\mathrm{S}^{1}$, Dori $\mathrm{I}^{1,3,4}$, Sparacello VS ${ }^{1 \S}$.

${ }^{1}$ Univ. Bordeaux, CNRS, MC, PACEA, UMR 5199, 33615 Pessac, France.

${ }^{2}$ CaSEs Research Group, Department of Humanities, Universitat Pompeu Fabra, c/Trias Fargas 25-27, Barcelona 08005, Spain.

${ }^{3}$ SABAP Soprintendenza Archeologia, Belle Arti e Paesaggio per le province di Verona, Rovigo e Vicenza, Piazza S. Fermo 3, 37121 Verona, Italy.

${ }^{4}$ Department of Biology, Laboratory of Anthropology, University of Florence, via del Proconsolo 12, 50122 Florence, Italy.

$\S$ Corresponding Author: Vitale Stefano Sparacello PACEA - UMR 5199 Université de BordeauxBâtiment B8 Allée Geoffroy Saint HilaireCS 5002333615 PESSAC CEDEX.vitale.sparacello@u-bordeaux.fr; vitosparacello@gmail.com

\section{Abstract}

This study offers a combined analysis of long bone mechanical properties (cross-sectional geometry, CSG), upper limb enthesopathies (ECs) and external auditory exostoses (EAE) among Neolithic people from Liguria (Italy). Previous CSG studies have suggested a high degree of mobility in mountainous terrain and sexual dimorphism in the upper limbs, with males more oriented towards uni-manual activities and females performing strenuous bimanual tasks. The aims of the study were to: 1) increase the sample size of the CSG study via the acquisition of 
27 surface 3D models; 2) provide a solid chronological framework through direct dating, to allow

28 for subsampling of individuals dated to the Impresso-Cardial Complex (ICC, c. 5800-5000 BCE) and the Square Mouthed Pottery Culture (SMP, c. 5000-4300 BCE); 3) integrate the results of CSG with information on ECs of the humeral epicondyles; 4) assess possible marine activities through analysis of EAEs. Results from the CSG analysis confirm previous studies, with no significant diachronic change. ECs in the humeral medial epicondyle parallel CSG adaptations: males tend to display more changes, especially unilaterally. Only one individual from the ICC period shows bilateral EAE, suggesting that marine activities were not prevalent. This study adds to our knowledge on activity patterns in the Neolithic in Liguria, and shows that integrating structural adaptations with information from specific entheseal alterations and exostoses can improve reconstructions of past habitual activities.

\section{Abstract French}

Nous avons analysé conjointement les propriétés mécaniques des os longs (géométrie des sections transverses, CSG), les enthésopathies des membres supérieurs (ECs) et les exostoses ont suggéré une grande mobilité en terrain montagneux et un dimorphisme sexuel important pour les membres supérieurs, les hommes étant davantage orientés vers des activités uni-manuelles et les femmes effectuant préférentiellement des tâches bimanuelles pénibles. Nous avons 1) augmenté la taille de l'échantillon de l'étude des CSG par l'acquisition de modèles 3D de surface ; 2) fourni un cadre chronologique solide grâce à de nouvelles datations radiocarbones AMS directes, permettant un sous-échantillonnage d'individus datés du complexe Impresso-Cardial (ICC, c. 5800-5000 BC) et de la culture des Vases à Bouche carrée céramique à bec carré (SMP, c. 5000-4300 BC) ; 3) intégré les résultats sur les CSG avec des informations sur les ECs des épicondyles de l’humérus; 4) évalué les activités marines possibles par l'analyse des EAE. Les résultats de l'analyse des CSG confirment les études antérieures, sans changement diachronique significatif. Les résultats pour les ECs dans l'épicondyle médial sont similaires à ceux pour les CSG du membre supérieur : les hommes ont tendance à avoir plus de changements, surtout unilatéralement. Un seul individu (daté de l’ICC) présente une EAE bilatérale, ce qui suggère des activités marines peu répandues. En plus d'enrichir nos connaissances sur les schémas d'activité dans le Néolithique ligurien, cette étude montre que l'intégration des adaptations structurelles 
57 avec les informations sur les ECs et les EAE peut améliorer les reconstructions des activités

58 habituelles dans le passé.

Keywords: habitual activities, subsistence patterns, cross-sectional geometry, entheseal changes, enthesopathies, external auditory meatus exostosis

Mots-clés : Activités quotidiennes ; modes de subsistance ; géométrie des sections transverses des diaphyses ; changements enthésiques ; enthésopathies ; exostoses du conduit auditif externe.

\section{Introduction}

The evaluation of plastic, epigenetic activity-related morphological adaptations (structural bone properties) and alterations (entheseal changes) in skeletal remains from archaeological contexts provides insights into sociocultural phenomena such as subsistence changes, craft specialization, the origins and development of sexual division of labour and social inequalities [1]. Among these sociocultural phenomena, the Neolithic Transition, i.e. the adoption of a production economy based on the domestication of plants and animals, is "one of the fundamental structural processes of human history” [2,3], and dramatically changed several aspects of the human experience, particularly habitual subsistence-related physical activity. This subsistence shift has been the focus of several studies aiming to reconstruct activity patterns, which generally show a decrease in mobility among farmers when compared to earlier hunter-gatherers (reviews in [4-7]).

However, the Neolithisation of Europe was probably a mosaic of different processes of replacement and integration, frontiers and "leap-frog” movements, growth and collapse, coexistence and warfare (e.g. [8-13]). Therefore, the skeletal consequences of the adoption of the Neolithic lifestyle are best explored at a micro-regional level [14]. Few regions in Europe show such a concentration of prehistoric sites from the Upper Palaeolithic to the Metal Ages as western Liguria (north-western Italy): Neolithic funerary sites are especially numerous and concentrated mostly around the municipality of Finale Ligure, where hundreds of karstic caves can be found within a radius of a few kilometres. After the early arrival of the Neolithic Impresso-Cardial Complex (ICC; c. 5800-5000 cal BC; [15-17]), Liguria saw the spread of the Square Mouth Pottery (SMP; 5000-4300 cal BC; [16,18-20]), and later was the access road for the diffusion of the Chassean in northern Italy from France (4300-3700 cal BC; $[18,21])$. This 
small strip of land between the mountains and the sea is therefore a pivotal region for our understanding of the cultural and biological dynamics that came into play during the spread and establishment of the Neolithic way of life in the western Mediterranean (e.g. [15,16, 22-25]).

Consequently, the functional adaptations of Ligurian Neolithic people have been the subject of several studies, especially via biomechanical analysis of long bones using the cross-sectional geometry method (CSG; review in [26,27]). For the lower limb, one of the main results of previous studies has been the discovery that the "sedentism" of Neolithic communities did not actually result in a low level of mobility, at least as inferred from lower limb biomechanics: Ligurian Neolithic individuals retained CSG properties that were more similar to those shown by Late Upper Palaeolithic hunters than by later agriculturalists, suggesting a high degree of mobility in a mountainous landscape [28,29,31,32,33]. These studies also showed evidence of significant sexual dimorphism in the degree of asymmetry of the upper limb, with males more asymmetrical, and females more symmetrical, than in modern industrialized groups and other agriculturalists [28,29,32,33]. This diverging pattern has been interpreted as indicative of a division of subsistence tasks between the sexes, in which the most strenuous and repetitive activities performed were mostly bi-manual for females, and mostly uni-manual for males [28].

This has been tentatively associated with subsistence activities that are apparent in the archaeological record, the most prominent of which may have been cereal processing using large bi-manual querns $([33,34,35])$ and woodworking and fodder harvesting with polished stone hatchets [28,33].

The Ligurian skeletal series was ideal to study human micro-regional adaptations, thanks to the small area from which it was unearthed. However, its chronological framework is more problematic. Most Neolithic layers had been excavated from the mid-19 ${ }^{\text {th }}$ century [36], in caves that, in some cases, showed evidence of human occupation from the Late Pleistocene to Roman times (e.g. [37,38]). Following the archaeological methods of the time [39], burials, and especially scattered human remains, were often excavated without keeping an accurate record of their spatial and stratigraphic positions. Probably due to the poor quality of the historic documentation, few burials were considered worthy of direct dating, and the individuals were labelled as likely/probably/possibly "Neolithic" or "Middle Neolithic" (which corresponds to the SMP culture in Liguria) depending on the material available about the associated culture. This 
limited the number of individuals that could be included in previous bioarchaeological studies, and the lack of a more precise chrono-cultural attribution has constantly prevented anthropologists from providing more than general insights into Ligurian "Neolithic" biocultural adaptations.

To begin to overcome the limitations of the skeletal series and its documentation, two research projects (see Acknowledgements section) performed a comprehensive re-assessment of the Ligurian material, including individual burials, partially disturbed burials and assemblages of scattered human remains. Depending on the completeness of the material, the study collected the information available on the biological profile (sex, age, pathology, osteometric and non-metric traits, dental anthropology), as well as funerary information (e.g. [39]). In addition, the study undertook complete direct dating of the Ligurian skeletal collection attributed to the Neolithic (c. 180 AMS dates), adding to the results from other recent studies $[23,24,39,40]$. The results of the dating campaign are reported in detail in another paper [41], but they indicate that the skeletal remains generally attributed to the Neolithic in Liguria span the period from the earliest Neolithic human occupation in the area through to the sixth and fifth millennium BCE, and in some cases belong to the Metal Ages or to historic times. For example, the double burial from Boragni, previously attributed to the Neolithic [42] and used in previous CSG research [30,33,43], actually dates to the Byzantine Period (1460 330 BP; 553-648 CE; Lyon-14599). The vast majority of the burials and skeletal remains fall chronologically within the period in which the Square Mouthed Pottery culture (SMP) has been attested in Liguria (c. 5000-4300 cal BCE; Table 1), with a small but significant presence of individuals belonging to an earlier phase (c. 5800-5000 BC, [39]). Thanks to direct dating, this new study was able to include individuals (complete and partial skeletons) that are certainly Neolithic, and to create subsamples based on the various chrono-cultural phases of the Neolithic in Liguria.

Furthermore, the new chronological framework makes it possible to assess whether the functional adaptations and behavioural correlates inferred by previous studies still hold when using a better defined and homogenous Neolithic skeletal collection from the SMP, and whether any diachronic change can be detected during the Neolithic. For the lower limb, the hypothesis of high degrees of mobility has important implications in terms of Neolithic adaptive strategies, logistic mobility and energy expenditure [7]; for the upper limb, sexual dimorphism and the 
hypothesized division of labour tap into issues of societal organization and identity, in addition to land use and energy expenditure to process food [33,34,35]. Confirmation is therefore needed that these results were not influenced by the inclusion in the sample of individuals from earlier pioneering Neolithic communities, or from the Metal Ages, for which technological/societal changes and a greater reliance on pastoralism have been proposed [43].

In addition, the project collected data on certain entheseal changes (ECs) that appear to correlate with habitual physical activity and are therefore ideal for integration with previous studies. Entheseal changes (ECs) are visible alterations on the skeleton at sites of tendon or ligament attachment, both fibrous (tendon or ligament attaching directly to the bone) and fibrocartilaginous (tendon or ligament attaching through transitional zones of a different composition) [44,45]. ECs have been associated with activity patterns in bioarchaeological studies, but their reliability as indicators of past behaviour is debated. It has been shown that a significant part of this issue is related to the methods used and the nature of the entheses under study [44,46-48]. Several factors have been mentioned by biological anthropologists to explain the occurrence of ECs at fibrocartilaginous sites, but three main causes can be identified from the medical literature (see [44] for a discussion): age (enthesopathies are more frequent in older individuals, especially after the age of 50), micro and macrotraumas, and systemic diseases (mainly DISH and spondyloarthropathies). Among the ECs that appear to correlate best with habitual activities, the one involving the medial epicondyle of the humerus could be related to strenuous uni-manual activities, especially those associated with the throwing motion [49-52]: ECs indeed appear to be frequent among prehistoric groups for which hunting involving throwing techniques has been hypothesized [51,52]. Given the divergent pattern of asymmetry by sex shown in the Neolithic Ligurian people described above, the study of ECs of the humeral epicondyle could provide further insights into the behavioural correlates of these upper limb adaptations and alterations.

Another bone alteration that may be relevant to draw inferences on behavioural correlates are the external auditory exostoses (EAEs), which are osseous exostoses that form in the external auditory canal as a result of an irritation of the periosteum. Several conditions can be responsible for this trait, but contact with cold water appears to be the main cause, and their prevalence and degree of expression has therefore been linked to the use of aquatic resources (for a review of the 
medical and anthropological literature, see $[53,54])$. EAE can be considered as one of the most informative of activity-related skeletal morphologies: it has a very well-known etiology, the amount of available clinical data is substantial, and it is possible to compare frequencies between current and past populations, with only minor methodological problems [54]. Although archaeological and faunal evidence suggest continuous use of marine resources throughout the Neolithic, a particular emphasis on terrestrial resources and on the use of the mountainous territory has been proposed for Liguria, based on dietary [55,56], zooarchaeological [57] and biomechanical evidence (see above). A low prevalence of EAEs would therefore be expected among Ligurian Neolithic people.

The overall purpose of the study was therefore to 1) perform a new CSG analysis with the benefit of the new chronological framework, and test whether past behavioural inferences still hold; 2) integrate the results from ECs, verifying whether these alterations support or contrast with structural bone adaptations; 3) propose new considerations on land vs marine oriented subsistence activities through the analysis of EAEs.

\section{Materials and Methods}

A total of 57 skeletons from eight nearby Ligurian sites (Finalese and Val Pennavaire; Figure 1) was included in this study, although the sample size is smaller depending on the specific analysis and on the completeness of the remains (Table 1, see also the Excel file named Supplementary Information Tables A). Because EAEs can develop during adolescence [54], individuals from c. 12 years old upwards were included in the study of this trait, while only individuals with fused long bone epiphyses were included in the CSG and ECs study. The osteometric measurements of two additional Ligurian Neolithic individuals were taken from the literature [42] to determine their sex via Discriminant Function Analysis (see below). Most individuals are directly dated to either the sixth or fifth millennium BCE; for the few individuals where dating failed or could not be done, the new chronological framework allows for a more robust chrono-cultural attribution based on contextual archaeological evidence, such as the presence of the stone cist for the Square Mouthed Pottery burials (Table 1; [41]).

\section{[Figure 1 (1.5 column) and Table 1 about here]}


The attribution of an individual to the "adult" age class was based on the completeness of epiphyseal fusion and dental maturation, integrated with dental wear [58]. The appearance of the pubic symphysis and auricular surface of the ilium was also considered [59-61]. Age at death of immature individuals was based, when possible, on dental maturation and eruption [62-64], and skeletal fusion [65-67], integrated when necessary with bone measurements [65,68].

The biological sex of the adult individuals in this study was re-assessed for all individuals via cranial and pelvic morphology, using the standards collected in Buikstra et al. [69], mandibular ramus flexure [70], and Bruzek [71] for the pelvic traits. Compared to previous studies, sex determination was changed for only one individual (Pollera 6246), from male to female (cf. Table 1 with [32]). For 13 individuals, the fragmentary nature of the remains did not allow attribution based on pelvic and/or cranial features, and sex was assessed via Discriminant Function Analysis (DFA) using the postcranial osteometric measurements of the individuals whose sex was determined from pelvic traits (e.g. [72-75]). Forward and backward stepwise selection of variables was undertaken for each individual where the sex was uncertain, and the preferred model was chosen based on discriminant power, significance, number of individuals used for the equation and number of variables included in the model. Due to the remarkable level of sexual dimorphism displayed by the Ligurian sample, the DFA produced models with a classification rate ranging from $90-100 \%$, and the posterior probabilities for attribution to a given sex was $>87 \%$ for the 13 uncertain individuals. All the osteometric measurements and equations are given in Supplementary Information Tables A.

Biomechanical analysis of functional postcranial adaptations via the cross-sectional geometry method (CSG) is based on the notion that bone tissue optimizes to its mechanical environment so as to maintain physiological strains within normal limits [26,27]. Bone tissue is deposited in the shaft's cross-section where mechanical loads require it to prevent strain in excess of the elastic limit, whereas below a certain strain threshold, the bone tissue is reabsorbed. By analyzing the cross-sections of the diaphysis, it is therefore possible to obtain variables that correlate with torsional bone rigidity (polar moment of area: J). Although the complexity of the factors influencing mechanical bone competence should always be taken into account when interpreting CSG results [26], it is generally assumed that variations in CSG properties correlate with activity levels and types, once the effect of body size is factored out to obtain a measure of "robusticity" 
234

235

236

237

238

239

240

241

242

243

244

245

246

247

248

249

250

251

252

253

254

255

256

257

258

259

260

261

262

263

[27]. Recent experimental evidence on modern athletes has substantially confirmed this rationale $[76,77,78]$. Integration of quantitative data derived from CSG with ethnographic and archaeological information has therefore been widely used to draw inferences about past subsistence strategies, degrees of mobility and other habitual activities [6,7,79].

For this comprehensive re-assessment of the skeletal series, all of the preserved long bones were scanned in 3D, using the DAVID SLS-3 structured light scanner, to make a new assessment of structural diaphyseal properties. CSG properties for 20 individuals were added in this study (cf. Table 1 with[28,29,30,32,33,43]), and cross-sections were reconstructed (35\% and 50\% from the distal end for the humeri, and $50 \%$ for the femur and tibia) from the surface scans, which were positioned virtually according to the reference planes following Ruff [80]. The cross-sections were obtained using the "slice" function in Netfabb Standard 2018 for PC (copyright Autodesk 2017), and the CSG properties calculated using a version of the SLICE program [81] adapted as a macro routine inserted in Scion Image release Beta 4.03. The "Solid CSG" method was used to estimate actual CSG properties from the periosteal contour via regression equations (provided in [43,82]), as justified in previous research [82-84]. All raw CSG data are given in Supplementary Information Tables A.

The variable used to quantify overall mechanical bone strength at a given diaphyseal level is the modulus $Z_{p}$ section (torsional and (twice) average bending strength [85,86]). True section moduli are calculated by dividing the polar second moment of area J (torsional and (twice) average bending rigidity of the beam) by the distance from the centroid section for torsion to the outermost fibre of the section [86]. Until recently, software packages did not provide true section moduli, which were therefore approximated by dividing $\mathrm{J}$ by the average radius of the section or by raising $\mathrm{J}$ to the power of $0.73[81,85,86]$. In this study, we use the latter method, which makes the results comparable to a larger body of literature, including previous studies on the same skeletal series. Although $\mathrm{J}^{0.73}$ is proportional to rather than strictly equivalent to $Z_{\mathrm{p}}$, given the substantial equivalency of the variables, this study will refer to $\mathrm{J}^{0.73}$ as $\mathrm{Z}_{\mathrm{p}}$, as done in previous research (e.g., [33]).

The mechanical loading on long bones is a function of physical activity, bone length and body mass [86]. To obtain a measure of "robusticity", which is assumed to correlate with the effects of activity, the estimate of overall bone strength $Z_{p}$ was scaled for size by dividing by mechanical 
264 bone length (as defined in Ruff [80]) and body mass [86]. Body mass was estimated from the

265 supero-inferior diameter of the femoral head following the guidelines in Trinkaus et al. [87].

266 Certain osteometric measurements for the determination of the appropriate level of the cross-

267 section and for standardization had to be estimated via regression equations based on the rest of

268 the sample, as commonly done in studies of this kind (e.g. $[87,88])$. The regression equations for

269 each estimated measurement are provided in Supplementary Information Tables A.

270 In order to characterize the prevalent use of one arm in activities causing strain, the degree of

271 humeral bilateral asymmetry in $\mathrm{J}$ was calculated using the formula $\left[\left(\mathrm{J}_{H}-\mathrm{J}_{\mathrm{L}}\right) / \mathrm{J}_{L}\right] \times 100$ (where $\mathrm{J}_{H}$

272 and $\mathrm{J}_{\mathrm{L}}$ are the higher and lower values of $\mathrm{J}$ between the two humeri, respectively) and expressed

273 as a percentage, following previous studies [32,33,89,90]. The resulting value represents an

274 absolute (non-directional) asymmetry. Asymmetry was calculated from the absolute values of $\mathrm{J}$

275 (i.e. not standardized by body size), because any prior size standardization would be elided.

276 Given their correspondence with mobility levels [76,78,91], lower limb CSG shape indices were

277 also analyzed. For the femur, the ratio between $I_{x}$ (second moment of area in the anteroposterior

278 plane) and $\mathrm{I}_{\mathrm{y}}$ (second moment of area in the mediolateral plane) was considered. For the tibia, the

279 ratio of $I_{\max }$ (maximum second moment of area) to $I_{\min }$, (minimum second moment of area) was

280 used.

281 Entheseal changes (EC) in the humeral medial and lateral epicondyles were recorded. Due to the 282 very small sample size, age-at-death is not controlled for in this study. Therefore, ECs at the 283 lateral epicondyle were scored in order to provide a basis for comparison for the EC frequencies

284 and distribution at the medial epicondyle. Recently, it has been found increasingly relevant to 285 distinguish two areas for the medial epicondyle [92,93]. Thus, unlike in previous studies (i.e.

$286[48,51,52])$, the area of the medial epicondyle was divided into two zones: the area of attachment 287 of the common flexor tendon (CFT) and the area of attachment of the anterior band of the ulnar 288 collateral ligament (UCL). ECs at the lateral epicondyle and the area of attachment of the CFT in 289 the medial epicondyle were scored on a 3-stage scale (A, B, C) following Villotte [46]. Several 290 changes at the attachment of the UCL were recorded (as absent or present): erosions and 291 cavitations of the surface, and geodes, were scored as ECG; longitudinal fissures and well292 defined pits with no clear interruption of the bone surface were scored as FP (see [92]:24; Figure 293 2). One of these features was enough to consider a change as present at the UCL attachment site. 
294 A composite variable for the whole medial epicondyle (ME) was then created, merging the data 295 for the UCL and CFT attachment sites. EC at the ME was considered as present if any change at the attachment sites of the CFT (stage B or C) and/or at the UCL was recorded. All raw data for EC are given in Supplementary Information Tables A. Asymmetry in ECs was assessed as the difference in scores between left and right sites for a given variable in a given individual. Differences between the sexes in terms of the number of asymmetrical individuals were assessed using Fisher's exact test. Differences between left and right sides within each sex in the presence/absence or aggregated score of a certain trait were also assessed using Fisher's exact test, although the independence assumption does not hold for paired humeri.

[Figure 2 ( 2 columns) about here]

EAEs were investigated through visual inspection of the auditory meatus under appropriate lighting, and recorded using a scoring system of the extent of occlusion previously applied by biological anthropologists (e.g. [94-97] and by clinicians (e.g. [98,99]). All raw data for EAEs are given in Supplementary Information Tables A.

The comparative samples for CSG properties consist of European Late Upper Palaeolithic (c. 20,000-10,000 BCE) and Italian Iron Age (Orientalizing-Archaic Period, c. 800-500 BCE, Abruzzo region) individuals collected during previous research [31,33,79,88,100,101].

\section{Results}

\subsection{Cross-sectional geometry}

Figures 3 and 4 show the main upper and lower limb CSG properties of the Ligurian sample, divided by sex and by chronological phases (c. 5800-5000 BCE: Impresso-Cardial Complex, ICC; c. 5000-4300 BCE: Square Mouthed Pottery, SMP). Note that the only individual dated to the Chassean (c. 4300-3700 BCE), for which only the left humerus could be analyzed, was not included in the figures. Raw data by individual are given in Supplementary Information. Although the sample size of the ICC individuals does not allow for a clear recognition of diachronic trends, their values are within the range of variability of SMP individuals for all the variables, in both the upper (Figure 3) and lower limbs (Figure 4).

[Figures 3 and 4 (both 2 columns) about here] 
Figure 5 and Table 2 show the comparison between upper limb CSG properties of SMP males and females when compared to Late Upper Palaeolithic hunter-gatherers and Iron Age agropastoralists. A diachronic trend of increasing robusticity in both humeri can be observed in males, although the SMP sample is not significantly different to LUP and IRON (Table 2). Humeral mid-distal bilateral asymmetry in SMP males is significantly lower than in LUP, but not significantly different to that in IRON males. Conversely, SMP females have the lowest asymmetry, although the comparison with IRON females is not significant at the $\alpha=0.05$ level after correcting for multiple comparisons (Table 2). Sexual dimorphism in the SMP sample is significant for right humeral robusticity and humeral bilateral asymmetry, with males showing higher values than females.

[Figure 5 ( 2 columns) and Table 2 about here]

Figures 6 and 7 and Table 2 show the comparison between lower limb CSG properties of SMP males and females when compared to Late Upper Palaeolithic hunter-gatherers and Iron Age agro-pastoralists (for this study the SMP individual Bergeggi 2 was not included, due to lower limb bending deformities probably due to rickets). No significant difference in femoral robusticity is present among the diachronic samples, while SMP females have higher tibial robusticity than IRON females (Figure 6, 7 and Table 2). A trend of temporally declining shape indices is observable in both the femur (Figure 6) and tibia (Figure 7), the decrease being particularly marked between SMP and IRON individuals especially. Both sexes in the SMP sample have significantly higher femoral shape indices than their IRON counterparts after correcting for multiple comparisons (Table 2). Sexual dimorphism in the SMP sample is significant for the shape indices of both the femur and tibia, the males showing higher values than females (Table 2).

\section{[Figures 6 and 7 (both 1.5 column) about here]}

\subsection{Humeral entheseal changes}

Table 3 shows the results of the evaluation of entheseal changes in the medial and lateral epicondyle of the humerus. For the lateral epicondyle, in both sides and in both sexes, ECs are frequent (ca. 50\% of the lateral epicondyles present stage B or C). No significant difference in the pattern of stage frequency could be detected, whether comparing sides within or between 
sexes. When considering individuals that could be examined bilaterally, the stage of ECs in the lateral epicondyle generally shows symmetry between sides (Table 3).

[Table 3 about here]

Results for the medial epicondyle differ from the lateral epicondyle in many ways. When considering the area of attachment of the CFT, no individual in the SMP or larger Ligurian Neolithic sample shows stage C. Stage B appears to be more represented in the right CFT area in males, but no variation by side or by sex is statistically significant. However, when considering individuals that could be examined bilaterally, males have consistently higher scores in the right CFT area when compared to females, which are more symmetrical. This result is significant at the $\alpha=0.05$ level after pooling the SMP and ICC individuals (Table 4).

[Table 4 about here]

Changes at the UCL attachment site are present in both sexes, but especially on the right side in males. Males have more lesions than females on the right side, but not on the left. Asymmetrical individuals are significantly more frequent in males than in females (Table 5)

[Table 5 about here]

When the CFT and UCL scores are aggregated, obtaining the "any change" variable for the medial epicondyle (ME any change), the pattern is similar to that described above: males show more changes especially on the right side, and asymmetrical individuals are more frequent in males than in females (Tables 6 and 7). However, the results are no longer statistically significant, probably due to the smaller sample size, when considering only individuals for which both the CFT attachment site and the anterior band of the UCL could be scored (Table 6). When aggregating the scores for individuals to which at least one score could be attributed, the results are statistically significant in the SMP sample (Table 7).

[Tables 6 and 7 about here]

No significant difference in humeral robusticity (both mid-distal and midshaft $\mathrm{Z}_{\mathrm{p}}$ ) or humeral bilateral asymmetry (mid-distal and midshaft HUMBA), as described by CSG data, could be detected between the subsamples based on sex and the medial/lateral epicondyle stage of entheseal change (Supplementary Information Tables B). However, SMP individuals (pooled 
sexes) with asymmetrical CFT stages of entheseal change tend to have more robust right and left humeri as described by mid-distal $\mathrm{Z}_{\mathrm{p}}$ (T-test $\mathrm{p}<0.05$; Supplementary Information Table B-2). Furthermore, in both in the pooled Ligurian Neolithic sample and the SMP sample, individuals with changes at the UCL (pooled sexes) show more robust right and left humeri as described by mid-distal $\mathrm{Z}_{\mathrm{p}}$ (T-test $\left.\mathrm{p}<0.05\right)$, and more asymmetrical humeri as described by the mid-distal bilateral asymmetry in $\mathrm{Z}_{\mathrm{p}}$ (T-test $\mathrm{p}<0.05$; Supplementary Information Tables B-3 and B-4). Although the significance of these results is mostly due to the observed sexual dimorphism in robusticity and asymmetry (Table 2) and in the higher prevalence of changes in the UCL in males (Table 5), it may be noticed that the same pattern is present by sex, although the results are not statistically significant (Figure 8).

Furthermore, a correspondence between changes in the UCL (ECG or ECG+FP) and humeral robusticity, asymmetry and laterality can be inferred from the categorized scatterplots (Figure 9). More robust and asymmetrical individuals will tend to have changes in the UCL, and the only individual with ECG on the left humerus is also the most asymmetrical left-dominant individual (Figure 9a). When considering the aggregate score for the medial epicondyle (ME any change) the correspondence between entheseal changes and CSG robusticity and laterality is less apparent, when considering only individuals for which both CFT and UCL could be scored (Figure 9c, and see above), and when including individuals to which only one score could be attributed (Figure 9d).

\section{[Figures 8 and 9 (both 1.5 column) about here]}

\section{3 external auditory canal exostosis (EAE)}

Among the 30 individuals that could be observed for EAE (Supplementary Information Table A), only one male individual dating to the sixth millennium BCE (Arma dell'Aquila 1 Richard) displays slight bilateral EAEs (Figure 10).

\section{[Figure 10 (1.5 column) about here]}

\section{Discussion}

This study aimed to reassess functional adaptations in the Ligurian Neolithic skeletal series, based on the new chronological framework recently provided by direct dating $[39,41]$. In 
addition to verifying whether the inferences on subsistence-related activity patterns made in the past using CSG (e.g. [28,30]) still hold, this study added new observations on certain entheseal changes that appear to correlate with habitual physical activity, located in the distal humerus [46,92] and in the external auditory meatus [54,97].

The direct dating results confirm that most of the skeletal series from Liguria overlap chronologically with the Square Mouthed Pottery culture (SMP), c. 5000-4300 BCE, i.e. the "Middle Neolithic" of Liguria [41]. With the new chronological framework, it became possible to attribute several individuals to this period, for which direct dating had failed or which could not be sampled, based on funerary treatment (e.g. Arene Candide 6PE, Arene Candide II BB, Pollera 32PE; [41]). On the other hand, certain individuals included in previous studies could no longer be assigned to the Neolithic (e.g. Boragni), or were assigned to a cultural tradition earlier than the SMP within the Impresso-Cardial Complex (ICC; e.g. most of the individuals from Arma dell'Aquila; [39]). Despite the exclusion of these individuals from the SMP sample, the Ligurian "Middle Neolithic" sample size for CSG analysis is still slightly larger than in previous studies, thanks to the inclusion of CSG data from 20 additional individuals that were excluded from previous analyses due to the lack of chrono-cultural attribution.

The characterization of functional adaptations of Ligurian SMP people does not change significantly based on this revised sample, which confirms the validity of previous observations and inferences on subsistence patterns [28-30,32,33]. The small size of the ICC sample does not allow for inferences on diachronic trends; however, most ICC individuals do not seem to deviate from the variability of the SMP sample. Lower limb CSG properties are still compatible with high levels of mobility in rugged terrain [30,31], showing values that are closer to Late Palaeolithic hunter-gatherers than later protohistorical agro-pastoralists. This further highlights how subsistence activities, particularly logistic mobility, among early agro-pastoralists in this region may have differed from later, more specialized forms of pastoralism [33]. However, more studies on controlled athlete vs sedentary samples are necessary to fully understand how different types of mobility influence femoral and tibial robusticity and lead to specific cross-sectional shapes (cf. our results with [76,78]).

The degree of asymmetry in humeral mid-distal mechanical rigidity of SMP males, around 20\%, is lower than that shown by LUP hunters, whose subsistence activities probably included a 
substantial amount of throwing [88], and later Iron Age agro-pastoralists, who performed unimanual sword training $[33,79,100]$. However, SMP male asymmetry is still relevant when compared to "physiological” asymmetry $(8-12 \%$; $[77,89])$, and especially when compared to SMP females, which show the lowest asymmetry among the comparative groups. The three females in the ICC sample show very low levels of mid-distal humeral asymmetry (between 24\%), suggesting that this trait was shared among Neolithic females in Liguria (less relevant for behavioural inferences is their relatively higher asymmetry at midshaft of the humerus, which is often influenced by the shape of the deltoid tuberosity [79]). Previous studies have suggested a possible causal relationship between the diverging pattern of asymmetry in males and females and the division of labour (see Introduction). However, caution is needed when inferring division of labour based on sexual dimorphism in structural properties, given the possible influence of hormonal factors and body size $(34,88)$. In this research, the focus was on determining whether CSG and ECs in the humerus produced compatible results.

Both CSG and ECs have been widely used in the past to draw inferences about activity patterns, although many studies have warned against simplistic interpretations of results given the number of concomitant factors that influence mechanical bone competence, entheseal appearance and other "markers of activities” (e.g. [26,102,103]). In particular, age and body size appear to be confounding factors for both methods. For CSG, mechanical properties seem to mostly reflect levels of activity during the pre- and peri-pubertal periods, while the extent of remodelling due to activity in later life is debated [26,27,104]. In addition, senescence does influence CSG properties, due to continued periosteal apposition to mechanically compensate for medullary expansion (especially in males; [105,106]). These limitations are presumed to have a relatively minor impact on the inferences about habitual activity and subsistence drawn from bioarchaeological samples, since it is assumed that individuals in prehistoric societies participated in subsistence activities as from late childhood, and died before reaching senescence. Hormonal and genetic factors may nevertheless confound behavioural interpretations [34,107]. In contrast, for ECs, the whole correlation with activity patterns is brought into question once age and body size are taken into account (e.g. [108-110]). Studies integrating CSG and ECs results for bioarchaeological reconstructions of activity patterns have at best found a general correspondence between the two methods (e.g. [111]), and more detailed tests between ECs scores and CSG values have failed to provide a consistent association [110,112-114]. This study 
has found similar results: individuals with higher scores in medial and lateral humeral epicondyle ECs are not consistently more robust. However, rather than expecting a general correspondence between EC scores and CSG robusticity, it is possible that specific entheseal changes, and especially their asymmetry, may be indicative of certain habitual activities.

The shape of the humeral medial epicondyle appears to have an influence on the pronationsupination range during elbow flexion and extension [115], and ECs in this area have been associated with trauma resulting from powerful extensions of the forearm, possibly related to throwing [49,50-52]. Prehistoric groups, especially Upper Palaeolithic hunters, often appear to show lesions in this area [51,52]. Among Upper Palaeolithic hunters, throwing has also been considered to be one of the main factors determining the remarkable degree of asymmetry in humeral mechanical rigidity, which is comparable or greater than that shown in professional tennis players or, indeed, throwers (e.g. [88]). A relationship between ECs in the medial epicondyle and CSG properties, particularly asymmetry, was therefore expected. Accordingly, in this study there is agreement between the inferences that could be drawn based on CSG and medial epicondyle ECs: males tend to be more asymmetrical than females, and tend to have lesions on the right side more frequently. In addition, although the sample size is small, there appears to be, within sexes, a correspondence between the presence of lesions in the dominant arm, in the anterior band of the UCL, and the level of humeral asymmetry. This relationship seems to be consistent with the laterality of CSG asymmetry: the only individual with somewhat relevant left-sided asymmetry is also the only individual with an erosion in the left anterior band of the UCL. However, this possible correspondence between biomechanical properties and ECs becomes less discernible when aggregating other entheseal changes in the medial epicondyle, further suggesting that, among ECs, erosions in the UCL may be particularly relevant for reconstructing activity. The very small sample size, however, makes these considerations speculative. Further research using a large sample with known activity is necessary to confirm the results found here.

In the Neolithic Ligurian sample, only one case of bilateral EAE (grade 1) has been recorded, in an individual from the ICC, Arma dell'Aquila 1. It is difficult to discuss frequencies of EAEs in a small sample [54]: although the total sample of Neolithic crania is 30, only three other individuals from the ICC period could be examined for EAE, and only unilaterally 
523

(Supplementary Information Table A). More archaeological and biochemical data on Neolithic Ligurian people are needed to understand whether this result could be compatible with a greater focus on marine resource use in the ICC Neolithic. No significant consumption of fish protein during the ICC and SMP periods has been proposed in light of the collagen isotopic composition of human bone $[40,55,56]$. However, archaeological and faunal evidence (e.g. shells, fish bones, fishing hooks, shell blow horns) are evidence of the continuous use of marine resources throughout the Neolithic [116]. In addition, EAE may be due to causes other than frequent contact with cold water, including infection, eczema, trauma and other pathological conditions affecting the normal homeostasis of the external ear canal [117,118]. Finally, the absence of EAE does not exclude aquatic activities. However, it should be noted that in populations for which isotopic data has indicated significant reliance on aquatic resources, EAEs tend to be very frequent and the occlusion of the ear canal is sometimes severe (i.e.; grades 2 or 3) $[54,94,97,119]$, which is not the case here. The results, although caution is necessary given the small sample size, seem compatible with a subsistence scenario where marine resource use was of relatively minor importance.

\section{Conclusions}

This study performed a re-assessment of long bone structural properties in the Neolithic Ligurian skeletal series, in the light of the new chronological framework produced by direct dating and new data derived by 3D scanning of the entire assemblage of long bones. As well as considering the plastic adaptation of the diaphyses, this study included an interpretative scenario with new data from skeletal alterations that are considered to be correlated with habitual activities. The analysis included entheseal changes in the humeral epicondyles, which have been associated with vigorous exertion of the upper limb, including the throwing motion, and the presence of exostoses in the external auditory meatus, which are considered to be an indicator of aquatic activities.

The biomechanical analysis results confirm previous studies: the data for lower limbs suggest high mobility; the upper limb is robust in both sexes, but males show significantly higher humeral asymmetry than females. No diachronic change was apparent when considering the subsampling based on chrono-cultural complexes within the Neolithic. Entheseal alterations in the humeral medial epicondyle are consistent with the results obtained from structural 
528 adaptations: males tend to show more changes than females, especially unilaterally on the more

529 mechanically robust side. In addition, individuals with lesions in the medial epicondyle tend to

530 have higher asymmetry. This result is potentially important because studies on adaptations and

531 alterations have often failed to produce consistent results. However, the sample size is very

532 small, and more research is necessary to confirm this correspondence between results derived

533 from structural adaptations and bone alterations.

534 Only one individual from the sixth millennium BCE shows bilateral external auditory meatus 535 exostosis, supporting the archaeological evidence suggesting that marine activities were not 536 prevalent during the Neolithic in Liguria. However, again, the sample size is too small, and

537 further evidence is necessary to investigate this issue.

538 This study has added to our knowledge on activity patterns in the Neolithic in Liguria, and 539 supports the careful integration of data on structural adaptations with information from specific entheseal alterations and exostoses to draw inferences about past habitual activities.

\section{Acknowledgements}

543 The authors would like to thank the Soprintendenza Archeologia, Belle Arti e Paesaggio per la 544 città metropolitana di Genova e le provincie di Imperia, La Spezia e Savona, for granting access 545 to skeletal collections, Superintendent Vincenzo Tiné and Officers Elisabetta Starnini, Marta 546 Conventi, Nico Radi, and Stefano Costa. We are grateful to the directors, curators, and staff of 547 the museums where the skeletal collections are preserved for their continuous assistance during 548 data collection: Daniele Arobba and Andrea De Pascale (Museo Archeologico del Finale, Finale 549 Ligure), Patrizia Garibaldi, Guido Rossi, Irene Molinari (Museo di Archeologia Ligure, Genova), 550 and Monica Zavattaro (Museo di Storia Naturale - Sezione di Antropologia e Etnologia, 551 Università degli Studi di Firenze). Thanks to Camillo Costa and the staff of the Museo Navale 552 Romano di Albenga. Thanks to Chiara Panelli, Stefano Rossi, Roberto Maggi, Vincenzo

553 Formicola, Paolo Biagi, Giovanni Murialdo, Gwenaëlle Goude, Sara Bernardini, Claudia Ferro, 554 Giuseppe “Cisque” Vicino, Maria Tagliafico, Elisa Bianchi, Simona Mordeglia, Walter 555 Siciliano, Jacopo Moggi-Cecchi, Giovanna Stefania, Luca Bachechi, Chiara Bullo and Brunetto 556 Chiarelli for their assistance during data collection and their scientific input. 
557 For their continuous assistance during the analysis, we are grateful to all the staff of the

558 University of Groningen Centre for Isotope Research (CIO), to Christine Oberlin, Centre de

559 Datation par le RadioCarbone, Université Claude Bernard Lyon1, and to Lucile Beck,

560 Responsable de la Plateforme Nationale LMC14 Laboratoire de Mesure du Carbone 14

561 (CEA/CNRS/IRD/IRSN/MCC)-LSCE CEA Saclay. The AMS dating performed at the Centre de

562 Datation par le RadioCarbone was supported by the “ARTEMIS” program.

563 The BUR.P.P.H project: Burial practices at the Pleistocene - Holocene transition: the changing

564 role of pathology, violence, and “exceptional events” (PI: VSS) received financial support from

565 the French State under the "Investing for the Future” Program, IdEx Bordeaux, reference ANR-

566 10-IDEX-03-02. The DEN.P.H. project: Dental anthropology at the Pleistocene-Holocene

567 transition - insights on lifestyle and funerary behaviour from Neolithic Liguria (Italy) (PI: ID) is

568 funded by the European Union’s Horizon 2020 research and innovation program under the Marie

569 Skłodowska-Curie grant agreement No 752626.

570

$571 \quad$ Literature Cited

572 1. Knüsel CJ, Sparacello V (2018) Functional morphology, postcranial, human. In:Trevathan

573 W, Cartmill M, Dufour D, Larsen C, O’Rourke D, Rosenberg K, Strier K (eds) The

$574 \quad$ International Encyclopedia of Biological

575 Anthropologydoi:10.1002/9781118584538.ieba0187

576 2. Bocquet-Appel J-P (2011a) When the world's population took off: the springboard of the

577 Neolithic Demographic Transition. Science 333:560-561

578 3. Bocquet-Appel J-P (2011b) The agricultural demographic transition during and after the 579 agriculture inventions. Curr Anthropol 52:S497-S510

580 4. Larsen CS (1995) Biological changes in human populations with agriculture. Ann Rev 581 Anthropol 24:185-213

582 5. Larsen CS (1997) Bioarchaeology, Cambridge University Press, Cambridge, $461 \mathrm{p}$

583 6. Pinhasi R, Stock J (eds) (2011) Human bioarchaeology of the Transition to $584 \quad$ Agriculture,Wiley-Liss, New York, 488 p

585 7. Carlson K, Marchi D (eds) (2014) Reconstructing mobility: environmental, behavioral, and 586 morphological determinants, Springer, New York, 295 p 
8. Lahr M, Foley R, Pinhasi R (2000) Expected regional patterns of Mesolithic-Neolithic human population admixture in Europe based on archaeological evidence. In: Renfrew C, Boyle K (eds) Archaeogenetics: DNA and the Population Prehistory of Europe. McDonald Institute for Archaeological Research, Monographs, Cambridge, pp 81-88

9. Clare K, Rohling EJ, Weninger B, et al (2008) Warfare in Late Neolithic/Early Chalcolithic Pisidia, southwestern Turkey. Climate induced social unrest in the late 7th millennium cal BC. Doc Praehist 25:65-92

10. Zeder MA (2008) Domestication and early agriculture in the Mediterranean basin: origins, diffusion, and impact. PNAS 105(33):11597-11604

11. Rowley-Conwy P (2011) Westward Ho! The spread of agriculture from Central Europe to the Atlantic. Curr Anthropol S52:431-451

12. Shennan S, Downey SS, Timpson A, et al (2013) Regional population collapse followed initial agriculture booms in mid-Holocene Europe. Nat Comm 4:2486

13. Meyer C, Lohr C, Gronenborn D, et al (2015) The massacre mass grave of SchöneckKikianstädten reveals new insights into collective violence in Early Neolithic Central Europe. PNAS 112(36):11217-11222

14. Stock JT, Pinhasi R (2011) Introduction. Changing paradigms in our understanding of the transition to agriculture: human bioarchaeology, behaviour and adaptation. In: Pinhasi R, Stock J (eds) Human bioarchaeology of the Transition to Agriculture. Wiley-Liss, New York, pp 1-17

15. Binder D (2013) Mésolithique et Néolithique ancien en Méditerranée nord-occidentale entre 7000 et 5500 cal. BCE: questions ouvertes sur les dynamiques culturelles et les procès d’interaction. Actes du XXVIIe Congrès préhistorique de France (Bordeaux-Les Eyzies, 2010). Société préhistorique française, Paris, pp 341-355

16. Binder D, Sénépart I (2010) La séquence de l’Impresso-Cardial de l’abri Pendimoun et l’évolution des assemblages céramiques en Provence. Mémoire LI de la Société Préhistorique française, pp 149-167

17. Binder D, Lanos P, Angeli L, et al (2017) Modelling the earliest north-western dispersal of Mediterranean Impressed Wares: new dates and Bayesian chronological model. Doc Praehist 44:54-77 
18. Maggi R (1997) The Radiocarbon Chronology. In: Maggi R (ed) Arene Candide: a functional and environmental assessment of the Holocene sequence (excavations Bernabò Brea-Cardini 1940-1950).Istituto Italiano di paleontologia umana, Il calamo, Roma, ns 5, pp 31-52

19. Pearce M (2013) Radiocarbon chronology for the spread of the early Neolithic north through the Tyrrhenian and Ligurian Seas area. In: Pearce M (ed) Rethinking the North Italian Early Neolithic. Accordia Research Insititute, University of London, London, pp 21-84

20. Del Lucchese A, Starnini E (2015) Aggiornamenti sulla fase antica della Cultura dei Vasi a Bocca Quadrata in Liguria da una revisione dei materiali ceramici in corso. In: Conventi M, Del Lucchese A, Gardini A (eds) Archeologia in Liguria, ns5 (2012-2013). Sagep Editrice Genova,pp 27-37

21. Crepaldi F (2001) Le Chasséen en Ligurie. Bull Soc Prehistor Fr 98(3):485-494

22. Branch NP, Black S, Maggi R, et al (2014) The neolithisation of Liguria (NW Italy): an environmental archaeological and palaeoenvironmental perspective. Environ Archaeol 19:196-213

23. Biagi P, Starnini E (2016) La cultura della Ceramica Impressa nella Liguria di Ponente (Italia Settentrionale): distribuzione, cronologia e aspetti culturali. In: Bonet Rosado H (ed) Del neolític a l'edat del bronze en el Mediterrani occidental. Estudis en homenatge a Bernat Martí Oliver. TV SIP 119, València, pp 35-49

24. Biagi P, Starnini E (2018) Gli scavi all’Arma dell’Aquila (Finale Ligure, Savona): le ricerche e I materiali degli scavi del Novecento. Quaderno 15. Società per la Preistoria e Protostoria della Regione Friuli-Venezia Giulia, Trieste, 260 p

25. Arobba D, Panelli C, Caramiello R, Gabriele M, Maggi R (2017) Cereal remains, plant impressions and 14C direct dating from the Neolithic pottery of Arene Candide Cave (Finale Ligure, NW Italy). J Archeol Sci: Rep 12:395-404

26. Pearson OM, Lieberman DE (2004) The aging of Wolff's 'Law': ontogeny and response to mechanical loading in cortical bone. Am J Phys Anthropol 47:63-99

27. Ruff CB, Holt B, Trinkaus E (2006) Who’s afraid of the big bad Wolff? 'Wolff's law' and bone functional adaptation. Am J Phys Anthropol 129:484-498

28. Marchi D, Sparacello VS, Holt BM, et al (2006) Biomechanical approach to the reconstruction of activity patterns in Neolithic Western Liguria, Italy. Am J Phys Anthropol 131:447-455 
29. Marchi D (2008) Relationships between lower limb cross-sectional geometry and mobility: the case of a Neolithic sample from Italy. Am J Phys Anthropol 137:188-200

30. Sparacello VS, Marchi D, Shaw CN (2014) The importance of considering fibular robusticity when inferring the mobility patterns of past populations. In: Carlson K, Marchi D (eds) Reconstructing mobility: environmental, behavioral, and morphological determinants. Springer, New York, pp 91-111

31. Sparacello VS, Villotte S, Shaw CN, et al (2018) Changing mobility patterns at the Pleistocene-Holocene transition: the biomechanics of the lower limb of Italian Gravettian and Mesolithic individuals. In: Cristiani E, Borgia V (eds) Palaeolithic Italy: Advanced studies on early human adaptations in the Apennine Peninsula. Sidestone Press, Leiden, pp 357-396

32. Sparacello VS, Roberts CA, Canci A, et al (2016) Insights on the paleoepidemiology of ancient tuberculosis from the structural analysis of postcranial remains from the Ligurian Neolithic (northwestern Italy). Int J Paleopath 15:50-64.

33. Sparacello VS, Pearson OM, Coppa A, et al (2011) Changes in robusticity in an Iron Age agropastoral group: the Samnites from the Alfedena necropolis (Abruzzo, Central Italy). Am J Phys Anthropol 144:119-130

34. Macintosh AA, Pinhasi R, Stock JT (2014) Divergence in male and female manipulative behaviors with the intensification of metallurgy in Central Europe. PLoS ONE 9(11):e112116

35. Sládek V, Ruff CB, Berner M, et al (2016) The impact of subsistence changes on humeral bilateral asymmetry in Terminal Pleistocene and Holocene Europe. J Hum Evol 92:37-49

36. De Pascale A (2008) Le prime esplorazioni nelle caverne ossifere del Finalese: tracce, ipotesi e scoperte ad opera di Issel, Perrando, Morelli, Rovereto, Rossi, Amerano. In: De Pascale A, Del Lucchese A, Raggio O (eds) La nascita della Paletnologia in Liguria: personaggi, scoperte e collezioni tra XIX e XX secolo. Atti del Convegno (Finale Ligure Borgo, 22-23 settembre 2006). Istituto Internazionale di Studi Liguri, Bordighera, pp 223-248

37. Bernabò Brea L (1946) Gli Scavi nella Caverna delle Arene Candide. Parte I Gli Strati con Ceramiche. Collezione di Monografie Preistoriche ed Archeologiche, I. Istituto di Studi Liguri, Bordighera 
677

678

679

680

681

682

683

684

685

686

687

688

689

690

691

692

693

694

695

696

697

698

699

700

701

702

703

704

705

706

38. Bernabò Brea L (1956) Gli Scavi nella Caverna delle Arene Candide (Finale Ligure). Parte Prima: Gli Strati con Ceramiche: Campagne di Scavo 1948-50. Collezione di Monografie Preistoriche ed Archeologiche, I. Istituto Internazionale di Studi Liguri, Bordighera

39. Sparacello VS, Panelli C, Rossi S, et al (2019) The re-discovery of Arma dell'Aquila (Finale Ligure, Italy): New insights on Neolithic funerary behavior from the sixth millennium BCE in the north-western Mediterranean. Quat Int 512:6781doi.org/10.1016/j.quaint.2019.02.003.

40. Mannino MA, Talamo S, Goude G, et al (2018) Analisi isotopiche e datazioni sul collagene osseo degli inumati dell'Arma dell'Aquila. In: Biagi P, Starnini E, (eds) Gli Scavi nell'Arma dell’Aquila (Finale Ligure, Savona): Le Ricerche e i Materiali degli Scavi del Novecento. Quaderno 15. Società per la Preistoria e Protostoria della Regione Friuli-Venezia Giulia, Trieste, pp 183-188

41. Sparacello VS, Varalli A, Rossi S, et al (2019) Large-scale AMS dating on human skeletal series from Ligurian caves (northwestern Italy) and the Neolithic peopling of the northwestern Mediterranean. Quat Intdoi.org/ 10.1016/j.quaint.2019.11.034.

42. Parenti R, Messeri P (1962) I resti scheletrici umani del Neolitico Ligure. Palaeontographia Italica 50:5-165

43. Marchi D, Sparacello VS, Shaw CN (2011) Mobility and lower limb robusticity of a pastoralist Neolithic population from North-Western Italy. In: Pinhasi R, Stock JY (eds) Human bioarchaeology of the Transition to Agriculture.John Wiley \& Sons, New York, pp 317-346

44. Villotte S, Knüsel CJ (2013) Understanding Entheseal Changes: Definition and Life Course Changes. Int J Osteoarchaeol 23:135-146

45. Villotte S, Assis S, Alves Cardoso F, et al (2016) In search of consensus: terminology for entheseal changes (EC). Int J Paleopath 13:49-55

46. Villotte S (2006) Connaissances médicales actuelles, cotation des enthésopathies: nouvelle méthode. Bull Mem Soc Anthropol Paris 18:65-85

47. Villotte S (2009) Enthésopathies et activités des hommes préhistoriques. Recherche méthodologique et application aux fossiles européens du Paléolithique Supérieur et du Mésolithique. Archaeopress, Oxford, 236 p 
48. Villotte S, Castex D, Couallier V, et al (2010a) Enthesopathies as occupational stress markers: evidence from the upper limb. Am J Phys Anthropol, 142 (2):224-234

49. Dutour O (1986) Enthesopathies (lesions of muscular insertions) as indicators of the activities of Neolithic Saharan populations. Am J Phys Anthropol 71:221-224

50. Dutour O (2000) Chasse et activités physiques dans la Préhistoire: les marqueurs osseux d'activités chez l’homme fossile. Anthropol Prehist 111:156-165

51. Villotte S, Churchill SE, Dutour OJ, et al (2010b) Subsistence activities and the sexual division of labor in the European Upper Paleolithic and Mesolithic: evidence from upper limb enthesopathies. J Hum Evol 59:35-43

52. Villotte S, Knüsel CJ (2014) “I sing of arms and of a man. . .”: medial epicondylosis and the sexual division of labour in prehistoric Europe. J Archaeol Sci 43:168-174

53. Kennedy GE (1986) The relationship between auditory exostosis and cold water: a latitudinal analysis. Am J Phys Anthropol 71:401-415

54. Villotte S, Knüsel CJ (2016) External auditory exostoses and prehistoric aquatic resource procurement. J Archaeol Sci: Rep 6(4):633-6

55. Le Bras-Goude G, Binder D, Formicola V, et al (2006) Stratégies de subsistance et analyse culturelle de populations néolithiques de Ligurie: approche par l'étude isotopique ( $\delta 13 \mathrm{C}$ et $\delta 15 N)$ des restes osseux. Bull Mem Soc Anthropol Paris 18:45-55

56. Goude G, Binder D, Del Lucchese A (2014) Alimentation et modes de vie néolithiques en Ligurie. In: Bernabo Brea M, Maggi R, Manfredini A (eds) Il Pieno Neolitico in Italia (8-10 juin Finale Ligure 2009). Riv Studi Liguri 77:371-387

57. Rowley-Conwy P (1997) The animal bones from Arene Candide (Holocene sequence): final report. In: Maggi R (ed) Arene Candide: a functional and environmental assessment of the Holocene sequence (excavations Bernabò Brea-Cardini 1940-1950). Isitituto Italiano di paleontologia umana, Il calamo, Roma, ns 5, pp 153-277

58. Molnar S (1972) Tooth wear and culture: a survey of tooth functions among some prehistoric population. Curr Anthropol 13:511-526

59. Brooks S, Suchey JM (1990) Skeletal age determination based on the os pubis: a comparison of the Acsádi-Nemeskéri and Suchey-Brooks methods. Hum Evol 5:227-238

60. Buckberry JL, Chamberlain AT (2002) Age estimation from the auricular surface of the ilium: a revised method. Am J Phys Anthropol 119:231-239 
738

739

740

741

742

743

744

745

746

747

748

749

750

751

752

753

754

755

756

757

758

759

760

761

762

763

764

765

766

767

768

61. Schmitt A (2005) Une nouvelle méthode pour estimer l’âge au décès des adultes à partir de la surface sacro-pelvienne iliaque. Bull Mem Soc Anthropol Paris 17(1-2):1-15

62. Ubelaker DH (1989) Human skeletal remains: excavation, analysis, interpretation, Taraxacum, Washington, $172 \mathrm{p}$

63. Smith BH (1991) Standards of human tooth formation and dental age assessment. In: KelleyMA, Larsen CS (eds) Advances in dental anthropology. Wiley-Liss, New York, pp 143-168

64. AlQahtani SJ, Hector MP, Liversidge HM (2010) The London atlas of human tooth and eruption. Am J Phys Anthropol 142:481-490

65. Schaefer M, Black S, Scheuer L (2009) Juvenile osteology - a laboratory and field manual, Academic Press, New York, 384 p

66. Ríos L, Cardoso HF (2009) Age estimation from stages of union of the vertebral epiphyses of the ribs. Am J Phys Anthropol 140:265-274

67. Cardoso HF, Ríos L (2011) Age estimation from stages of epiphyseal union in the presacral vertebrae. Am J Phys Anthropol 144:238-247

68. Boccone S, Micheletti Cremasco M, Bortoluzzi S, et al (2010) Age estimation in subadults Egyptioan remains. J Comp Hum Biol 61:337-358

69. Buikstra JE, Ubelaker DH (1994) Standards for Data Collection from Human Skeletal Remains, Arkansas Archaeological Survey Research Series No 44, Fayetteville, 218 p

70. Loth SR, Henneberg M (1996) Mandibular ramus flexure: a new morphologic indicator of sexual dimorphism in the human skeleton. Am J Phys Anthropol 99:473-485

71. Bruzek J (2002) A method for visual determination of sex using the human hip bone. Am J Phys Anthropol 117:157-168

72. Thieme FP, Schull WJ (1957) Sex determination of the skeleton. Hum Biol 29:242-273.

73. Richman EA, Michel ME, Schulter-Ellis FP, et al (1979) Determination of sex by discriminant function analysis of postcranial skeletal measurements. J Forensic Sci 24:159_ 167.

74. Steyn M, Işcan MY (1997) Sex Determination from the Femur and Tibia in South African Whites. Forensic Sci Int90(1-2):111-119

75. Murail P, Bruzek J, Braga J (1999) A new approach to sexual diagnosis in past populations, Practical adjustments from Van Vark’s procedure. Int J Osteoarchaeol 9:39-53 
76. Shaw C, Stock J (2009a) Intensity, repetitiveness, and directionality of habitual adolescent mobility patterns influence the tibial diaphysis morphology of athletes. Am J Phys Anthropol 140:149-159

77. Shaw C, Stock J (2009b) Habitual throwing and swimming correspond with upper limb diaphyseal strength and shape in modern human athletes. Am J Phys Anthropol 140:160-172

78. Macintosh AA, Stock JT (2019) Intensive terrestrial or marine locomotor strategies are associated with inter- and intra-limb bone functional adaptation in living female athletes. Am J Phys Anthropol DOI: 10.1002/ajpa.23773

79. Sparacello VS, d’Ercole V, Coppa A (2015) A bioarchaeological approach to the reconstruction of changes in military organization among Iron Age Samnites (Vestini) from Abruzzo, central Italy. Am J Phys Anthropol 156:305-316

80. Ruff CB (2002) Long bone articular and diaphyseal structure in Old World monkeys and apes. I: locomotor effects. Am J Phys Anthropol 119:305-342

81. Nagurka ML, Hayes WC (1980) An interactive graphics package for calculating crosssectional properties of complex shapes. J Biomech 13:59-64

82. Sparacello VS, Pearson OM (2010) The importance of accounting for the area of the medullary cavity in cross-sectional geometry: a test based on the femoral midshaft. Am J Phys Anthropol 143:612-624

83. Stock JT, Shaw CN (2007) Which measures of skeletal robusticity are robust? A comparison of external methods of quantifying diaphyseal strength to cross-sectional geometric properties. Am J Phys Anthropol 134:412-423

84. Macintosh AA, Davies TG, Ryan TM, et al (2013) Periosteal versus true cross-sectional geometry: a comparison along humeral, femoral, and tibial diaphysis. Am J Phys Anthropol150:442-452

85. Ruff CB (2018) Quantifying skeletal robusticity. In: Ruff CB (ed) Skeletal variation and adaptation in Europeans: Upper Paleolithic to the Twentieth Century. John Wiley and Sons, Inc., New York, pp 39-47.

86. Ruff CB (2000) Body size, body shape, and long bone strength in modern humans. J Hum Evol 38:269-290

87. Trinkaus E, Ruff CB (2012) Femoral and tibial diaphyseal cross-sectional geometry in Pleistocene Homo. PaleoAnthropology 2012:13-62 
88. Sparacello VS, Villotte S, Shackelford LL, et al (2017) Patterns of Humeral Asymmetry among Late Pleistocene Humans. CR Palevol 16(5-6):680-689

89. Trinkaus E, Churchill SE, Ruff CB (1994) Postcranial robusticity in Homo. II. humeral bilateral asymmetry and bone plasticity. Am J Phys Anthropol 93:1-34

90. Rhodes JA, Knüsel CJ (2005) Activity-related skeletal change in medieval humeri: crosssectional and architectural alterations. Am J Phys Anthropol 128:536-546

91. Holt BM (2003) Mobility in Upper Paleolithic and Mesolithic Europe: evidence from the lower limb. Am J Phys Anthropol 122:200-215

92. Martiarena ML (2016) Analyse d'un marquer d'activité dans une population humaine préhistorique. M2 Thesis, Université libre de Bruxelles, Bruxelles

93. Polet C, Martiarena ML, Villotte S, et al (2019) Throwing activities among Neolithic populations from the Meuse River Basin (Belgium, 4500-2500 BC) with a focus on adolescents. Child Past 12(2):81-95

94. Crowe F, Sperduti A, O'Connell TC, et al (2010) Water-related occupations and diet in two Roman coastal communities (Italy, first to third century AD): correlation between stable carbon and nitrogen isotope values and auricular exostosis prevalence. Am J Phys Anthropol 142:355-366

95. Standen VG, Arriaza BT, Santoro CM (1997) External auditory exostosis in prehistoric Chilean populations: A test of the cold water hypothesis. Am J Phys Anthropol 103:119-129

96. Velasco-Vazquez J, Betancor-Rodriguez A, Arnay-De-La Rosa M, et al (2000) Auricular exostoses in the prehistoric population of Gran Canaria, Am J Phys Anthropol 112:49-55

97. Villotte S, Stefanović S, Knüsel CJ (2014) External auditory exostoses and aquatic activities during the Mesolithic and the Neolithic in Europe: Results from a large prehistoric sample. Anthropologie LII/1(1):73-89

98. Cooper A, Tong R, Neil R, et al (2010) External auditory canal exostoses in white water kayakers. Br J Sports Medicine 44:144-147

99. Hurst W, Bailey M, Hurst B (2004) Prevalence of external auditory canal exostoses in Australian surfboard riders. J Laryngol Otol 118:348-351

100. Sparacello VS (2013) The Bioarchaeology of Changes in Social Stratification, Warfare, and Habitual Activities among Iron Age Samnites of Central Italy. PhD Thesis, University of New Mexico, Albuquerque 
831 101. Villotte S, Samsel M, Sparacello VS (2017) The paleobiology of the two adult skeletons

832 from Baousso da Torre (Bausu da Ture) (Liguria, Italy): implications for our understanding of Gravettian lifestyle. Comptes Rendus Palevol 16:462-473

834 102. Meyer C, Nicklisch N, Held P, et al (2011) Tracing patterns of activity in the human

835 skeleton: An overview of methods, problems, and limits of interpretation. J Comp Hum Biol 62:202-217

103. Jurmain R, Alves Cardoso F, Henderson C, et al (2012) Bioarchaeology's Holy Grail: The reconstruction of activity. In: Grauer AL (ed) A Companion to Paleopathology. WileyBlackell, New York, pp 531-552

104. Lazenby RA (1990) Continuing periosteal apposition II: the significance of peak bone mass, strain equilibrium, and age-related activity differentials for mechanical compensation in human tubular bones. Am J Phys Anthropol 82:473-484

105. Martin RB, Atkinson PJ (1977) Age and sex-related changes in the structure and strength of the human femoral shaft. J Biomech 10:223-231

106. Ruff C, Hayes W (1988) Sex differences in age-related remodeling of the femur and tibia.

107. Agostini G, Holt BM, Relethford JH (2018) Bone functional adaptation does not erase neutral evolutionary information. Am J Phys Anthropol 166.10.1002/ajpa.23460.

108. Alves Cardoso FA, Henderson CY (2010) Enthesopathy formation in the humerus: Data from known age-at-death and known occupation skeletal collections. Am J Phys Anthropol 141:550-560

109. Weiss E (2007) Muscle markers revisited: Activity pattern reconstruction with controls in a Central California Amerind population. Am J Phys Anthropol 133:931-940

110. Nikita E, Xanthopoulou P, Bertsatos A, et al (2019) A three-dimensional digital microscopic investigation of entheseal changes as skeletal activity markers. Am J Phys Anthropol DOI: 10.1002/ajpa.23850

111. Lieverse AR, Stock JT, Katzemberg MA, et al (2011) The bioarcheology of habitual activity and dietary change in the Siberian Middle Holocene. In: Pinhasi R, Stock J (eds) Human bioarchaeology of the Transition to Agriculture. Wiley-Liss, New York, pp 265-291. 112. Niinimäki S (2012) The relationship between musculoskeletal stress markers and biomechanical properties of the humeral diaphysis. Am J Phys Anthropol 147:618-628 
862 113. Michopoulou E, Nikita E, Henderson CY (2017) A test of the effectiveness of the 863 Coimbra method in capturing activity-induced entheseal changes. Int J Osteoarchaeol $864 \quad 27: 409-417$

865 114. Michopoulou E, Nikita E, Valakos ED (2015) Evaluating the efficiency of different 866 recording protocols for entheseal changes in regards to expressing activity patterns using 867 archival data and cross-sectional geometric properties. Am J Phys Anthropol 158:557-568

868 115. Ibáñez-Gimeno P, Galtés I, Jordana X, et al (2013) Entheseal changes and functional 869 implications of the humeral medial epicondyle. IntJ Osteoarch 23:211-220

870 116. Desse-Berset N, Desse J (1999) Les poissons. In: Tinè S (ed) Il Neolitico della caverna 871 delle Arene Candide (scavi 1972-1977).Istituto Internazionale di Studi Liguri, Bordighera, pp $872 \quad 36-50$

873 117. Di Bartolomeo J, Paparella M, Meyerhoff W (1991) Cysts and tumors of the external ear. 874 In: Shumrick D, Gluckman J, Meyerhoff W (eds) Otolaryngology. 3rd edition, 2:1243-1258. 875 118. Fowler EP, Osmun PM (1942) New bone growth due to cold water in the ears, Arch 876 Otolaryngol Head Neck Surg 36:455-466

877 119. Kusaka S, Hyodo F, Yumoto T, et al (2010) Carbon and nitrogen stable isotope analysis 878 on the diet of Jomon populations from two coastal regions of Japan. J Archaeol Sci 37:1968$879 \quad 1977$ 


\begin{tabular}{|c|c|c|c|c|c|c|c|}
\hline Individual ID & Analysis & $\begin{array}{l}\text { Age } \\
\text { Class }\end{array}$ & $\begin{array}{c}\text { Age } \\
\text { Dental }\end{array}$ & $\begin{array}{c}\text { Age } \\
\text { Postcr. }\end{array}$ & Sex & $\begin{array}{l}\text { AMS date } \\
\text { cal. } 95.4 \%\end{array}$ & $\begin{array}{l}\text { Chrono- } \\
\text { cultural } \\
\text { attribution }\end{array}$ \\
\hline Acqua o Morto 251+254 & $\mathrm{CSG}^{*}, \mathrm{EAE}$ & Adult & $30-50$ & $\mathrm{U}$ & $\mathrm{M}$ & $4797-4695$ & SMP \\
\hline Acqua o Morto $252+253$ & CSG*, ECs & Adult & $30-50$ & $\mathrm{U}$ & $\mathrm{F}$ & $5301-5073$ & ICC \\
\hline $\begin{array}{l}\text { Arene Candide 6PE } 3 \\
\text { Perrando }\end{array}$ & CSG, ECs & Adult & $30-50$ & $30-50$ & $\mathrm{M}$ & $\begin{array}{c}\text { failed (prob. V } \\
\text { mill. BCE) } \\
(5657-4620)^{1}\end{array}$ & SMP \\
\hline Arene Candide 1 Tinè & $\mathrm{CSG}^{*}, \mathrm{EAE}$ & Late adol. & $15-18$ & $15-17$ & M & $4704-4374$ & SMP \\
\hline Arene Candide 2 Tinè & $\begin{array}{l}\text { CSG, EAE, } \\
\text { ECs }\end{array}$ & Adult & $30-50$ & $30-50$ & M & $5209-5011$ & ICC \\
\hline $\begin{array}{l}\text { Arene Candide } 6622.1 \mathrm{FI}+ \\
6730.2 \mathrm{FI}\end{array}$ & $\begin{array}{l}\mathrm{CSG}^{*}, \mathrm{EAE} \\
\text { ECs }\end{array}$ & Adult & $\mathrm{U}$ & $\mathrm{U}$ & $\mathrm{F}$ & $5208-5000$ & ICC \\
\hline Arene Candide 6730.1FI & CSG*, ECs & Young Adult & $\mathrm{U}$ & $20-30$ & $\mathrm{~F}$ & $4688-4540$ & SMP \\
\hline Arene Candide 7PE & $\begin{array}{l}\text { CSG, EAE, } \\
\text { ECs }\end{array}$ & Adult & $30-50$ & $30-50$ & M & $4767-4586$ & SMP \\
\hline Arene Candide 8PE & $\begin{array}{l}\text { CSG, EAE, } \\
\text { ECs }\end{array}$ & Adult & $30-50$ & $30-50$ & M & $4708-4555$ & SMP \\
\hline Arene Candide II BB & $\mathrm{CSG}^{*}, \mathrm{ECs}$ & Adult & $\mathrm{U}$ & $\mathrm{U}$ & $\mathrm{F}$ & $\begin{array}{l}\text { failed (prob. V } \\
\text { mill. BCE) }\end{array}$ & SMP \\
\hline Arene Candide III BB & $\begin{array}{l}\text { CSG, EAE, } \\
\text { ECs }\end{array}$ & Adult & $30-50$ & $30-50$ & M & 4800-4619 & SMP \\
\hline $\begin{array}{l}\text { Arene Candide IV BB (+ } \\
6726 \mathrm{FI}+6730.7 \mathrm{FI})\end{array}$ & $\begin{array}{l}\text { CSG, EAE, } \\
\text { ECs }\end{array}$ & Young Adult & $20-30$ & $20-30$ & $\mathrm{~F}$ & $4766-4558$ & SMP \\
\hline Arene Candide IX BB & $\begin{array}{l}\text { CSG, EAE, } \\
\text { ECs }\end{array}$ & Adult & $30-50$ & $30-50$ & $\mathrm{~F}$ & $4779-4611$ & SMP \\
\hline Arene Candide VI BB & $\begin{array}{l}\text { CSG, EAE, } \\
\text { ECs }\end{array}$ & Adult & $30-50$ & $\mathrm{U}$ & M & $4581-4457$ & SMP \\
\hline Arene Candide VII BB & $\begin{array}{l}\text { CSG, EAE, } \\
\text { ECs }\end{array}$ & Adult & $30-50$ & $30-50$ & $\mathrm{~F}$ & $4778-4603$ & SMP \\
\hline Arma dell'Aquila 1 Richard & $\begin{array}{l}\text { CSG, EAE, } \\
\text { ECs }\end{array}$ & Adult & $30-50$ & $30-50$ & M & $5361-5221$ & ICC \\
\hline Arma dell'Aquila 1 Zambelli & $\begin{array}{l}\text { CSG, EAE, } \\
\text { ECs }\end{array}$ & Adult & $30-50$ & $\mathrm{U}$ & $\mathrm{F}$ & $4723-4551$ & SMP \\
\hline Arma dell'Aquila 2 Richard & $\begin{array}{l}\text { CSG, EAE, } \\
\text { ECs }\end{array}$ & Adult & $>50$ & $\mathrm{U}$ & M & $5213-5010$ & ICC \\
\hline Arma dell'Aquila 3 Richard & CSG*, ECs & Adult & $30-50$ & $\mathrm{U}$ & M & $5202-4962$ & ICC \\
\hline Arma dell'Aquila 5 Richard & CSG, EAE & Adult & $30-50$ & $\mathrm{U}$ & $\mathrm{F}$ & $5208-4956$ & ICC \\
\hline Arma dell'Aquila RS5 & $\mathrm{CSG}^{*}$ & Adult & $\mathrm{U}$ & $\mathrm{U}$ & $\mathrm{U}$ & $5750-5645$ & ICC \\
\hline Arma dell'Aquila RS9 & $\mathrm{CSG}^{*}$ & Adult & $\mathrm{U}$ & $\mathrm{U}$ & $\mathrm{F}$ & $5206-4911$ & ICC \\
\hline Bergeggi (IV) 3573 + 3573bis & EAE & Adult & $\mathrm{U}$ & $30-50$ & $\mathrm{~F}$ & $\begin{array}{l}\text { failed (prob. V } \\
\text { mill. BCE) }\end{array}$ & SMP \\
\hline Bergeggi 1 Modigliani & EAE & Adolescent & $\begin{array}{c}13-19 \\
(12-15 ?)\end{array}$ & $12-13$ & $\mathrm{U}$ & $4527-4370$ & SMP \\
\hline Bergeggi 2 Modigliani & $\begin{array}{l}\mathrm{CSG}^{*}, \mathrm{EAE} \\
\text { ECs }\end{array}$ & Young Adult & 20-30 & $30-50$ & M & $4680-4494$ & SMP \\
\hline Bergeggi 3 Modigliani & CSG, ECs & Adult & $\mathrm{U}$ & $\mathrm{U}$ & $\mathrm{F}$ & $4488-4364$ & SMP \\
\hline $\begin{array}{l}\text { Bergeggi } 4 \text { Modigliani + } \\
\text { PE01177, 6893FI }\end{array}$ & CSG, ECs & Young Adult & $\mathrm{U}$ & $17-19$ & $\mathrm{M}$ & $4680-4494$ & SMP \\
\hline Bergeggi 5 Modigliani & CSG, EAE & Adult & $\mathrm{U}$ & $\mathrm{U}$ & $\mathrm{F}$ & $4539-4374$ & SMP \\
\hline La Matta 01085 & EAE & Young Adult & $20-30$ & $\mathrm{U}$ & M? & $\begin{array}{l}\mathrm{n} / \mathrm{a} \text { (prob. V mill. } \\
\text { BCE) }\end{array}$ & SMP \\
\hline
\end{tabular}




\begin{tabular}{|c|c|c|c|c|c|c|c|}
\hline La Matta 01086 & EAE & Adolescent & $\begin{array}{l}11.5- \\
12.5\end{array}$ & $\mathrm{U}$ & $\mathrm{U}$ & $\begin{array}{l}\text { n/a (prob. V mill. } \\
\text { BCE) }\end{array}$ & SMP \\
\hline Nasino 1 & $\begin{array}{l}\text { CSG*, EAE, } \\
\text { ECs }\end{array}$ & Late adol. & $13-19$ & $16-20$ & M & $4232-4000$ & Chassean \\
\hline Pian del Ciliegio Adult & CSG, ECs & Young Adult & $20-30$ & $20-30$ & M & $4690-4544$ & SMP \\
\hline Pipistrelli 3_El Muerto N3 & CSG*, ECs & Adult & $>20$ & $\mathrm{U}$ & M & $4723-4614$ & SMP \\
\hline Pipistrelli 5 dep23.I.28 Cirillo & CSG*, ECs & Adult & $\mathrm{U}$ & $\mathrm{U}$ & M & $5016-4844$ & SMP \\
\hline $\begin{array}{l}\text { Pipistrelli } 6 \text { dep 23.II.41 } \\
\text { Angelina }\end{array}$ & CSG*, ECs & Adult & $\mathrm{U}$ & $30-50$ & M & $4995-4810$ & SMP \\
\hline Pollera 1 Tiné & $\begin{array}{l}\text { CSG, EAE, } \\
\text { ECs }\end{array}$ & Young Adult & $20-30$ & $20-30$ & $\mathrm{~F}$ & $4712-4552$ & SMP \\
\hline Pollera 10PE & CSG, ECs & Young Adult & $\mathrm{U}$ & $20-30$ & M & $4701-4550$ & SMP \\
\hline Pollera 110a & $\mathrm{CSG}^{*}, \mathrm{ECs}$ & Adult & $\mathrm{U}$ & $\mathrm{U}$ & $\mathrm{F}$ & $4690-4544^{2}$ & SMP \\
\hline Pollera 110b & CSG* & Adult & $\mathrm{U}$ & $\mathrm{U}$ & $\mathrm{F}$ & $4690-4544^{2}$ & SMP \\
\hline Pollera 12PE & $\begin{array}{l}\text { CSG, EAE, } \\
\text { ECs }\end{array}$ & Adult & $30-50$ & $30-50$ & $\mathrm{~F}$ & $4794-4687$ & SMP \\
\hline Pollera 13PE & $\begin{array}{l}\text { CSG, EAE, } \\
\text { ECs }\end{array}$ & Adult & $30-50$ & $30-50$ & M & $4686-4527$ & SMP \\
\hline Pollera 14PE & $\begin{array}{l}\text { CSG, EAE, } \\
\text { ECs }\end{array}$ & Adult & $30-50$ & $30-50$ & $\mathrm{~F}$ & $4786-4616$ & SMP \\
\hline Pollera 1PE Issel-Morelli & EAE & Adolescent & $10-12$ & $<11$ & $\mathrm{U}$ & $4786-4616$ & SMP \\
\hline Pollera 22PE & CSG*, ECs & Adult & $\mathrm{U}$ & $30-50$ & M & $4786-4616$ & SMP \\
\hline Pollera 30PE & $\begin{array}{l}\text { CSG, EAE, } \\
\text { ECs }\end{array}$ & Adult & $30-50$ & $30-50$ & M & $4689-4543$ & SMP \\
\hline Pollera 31PE & $\mathrm{CSG}^{*}$ & Adult & $\mathrm{U}$ & $30-50$ & M & $4701-4548$ & SMP \\
\hline Pollera 32PE & CSG, ECs & Adult & $\mathrm{U}$ & $30-50$ & M & $\begin{array}{l}\text { failed (prob. V } \\
\text { mill. BCE) }\end{array}$ & SMP \\
\hline Pollera 33PE & $\begin{array}{l}\text { CSG, EAE, } \\
\text { ECs }\end{array}$ & Adult & $30-50$ & $30-50$ & $\mathrm{~F}$ & $4711-4555$ & SMP \\
\hline Pollera 34PE & EAE & Adolescent & $13-19$ & $11-16$ & $\mathrm{U}$ & $4723-4558$ & SMP \\
\hline Pollera 6246PE & $\begin{array}{l}\text { CSG, EAE, } \\
\text { ECs }\end{array}$ & Adult & $30-50$ & $30-50$ & $\mathrm{~F}$ & $4650-4462$ & SMP \\
\hline Pollera 6673.6FI & $\mathrm{CSG}^{*}$ & Adult & $\mathrm{U}$ & $\mathrm{U}$ & $\mathrm{U}$ & $4879-4724$ & SMP \\
\hline Pollera 6690bis.3FI & $\mathrm{CSG}^{*}, \mathrm{ECs}$ & Young Adult & $\mathrm{U}$ & $20-30$ & $\mathrm{~F}$ & $4794-4687$ & SMP \\
\hline Arene Candide 6621.1 & $\begin{array}{l}\text { Osteometrics } \\
\text { only }\end{array}$ & Adolescent & $13-19$ & $12-16$ & $\mathrm{~F}$ & $4726-4557$ & SMP \\
\hline $\begin{array}{l}\text { Arene Candide } \\
6634.1+6626.1+6730.2 \text { tris }\end{array}$ & $\begin{array}{l}\text { Osteometrics } \\
\text { only }\end{array}$ & Adult & $\mathrm{U}$ & $\mathrm{U}$ & $\mathrm{F}$ & $4792-4688$ & SMP \\
\hline $\begin{array}{l}\text { Arene Candide I BB 6731.1FI } \\
+6627.2 \mathrm{FI}\end{array}$ & $\begin{array}{l}\text { Osteometrics } \\
\text { only }\end{array}$ & Adolescent & $\mathrm{U}$ & $13-17$ & $\mathrm{U}$ & $4690-4544$ & SMP \\
\hline Arene Candide V BB & $\begin{array}{l}\text { Osteometrics } \\
\text { only }\end{array}$ & Adolescent & c. 15 & $14-16$ & $\mathrm{U}$ & $4720-4557$ & SMP \\
\hline Pipistrelli 4_dep23.III.73_76 & $\begin{array}{l}\text { Osteometrics } \\
\text { only }\end{array}$ & Young Adult & $20-30$ & $20-30$ & $\mathrm{~F}$ & $5207-4909$ & ICC \\
\hline
\end{tabular}

Table 1 - Individuals from the Neolithic in Liguria included in this study, indicating the analyses performed for each. Asterisks indicate the individuals for which CSG data was collected for this study (cf. the last CSG sample [32]). A more detailed list of individuals examined for this study, including their uncalibrated date and the museum where they are preserved, is available as Supplementary Information (excel file “Supplementary Information Tables A”).See also [41].

CSG: cross-sectional geometry; EAE: external auditory exostoses; ECs: entheseal changes; U: sex undetermined; M: male; F: female; SMP: Square Mouthed Pottery; ICC; Impresso-Cardial Complex. 
$892{ }^{1}$ date from previous studies with large error (see excel file "Supplementary Information_raw data by 893 analysis”). ${ }^{2}$ Date belongs to PO 110c, individual found in close association with PO 110a-b.

894 Table 1 - Individus néolithiques de Ligurie inclus dans l'étude, avec pour chacun d'eux une indication 895 des analyses effectuées. Une liste plus détaillée, incluant les données radiocarbones non-calibrées et les 896 lieux de conservation, est disponible dans l'annexe Table A. Voir également [41].

897 U: sexe indeterminé; M: homme; F: femme; ${ }^{1}$ date provenant d'études antérieures avec une large erreur 898 (voir l'annexe “Supplementary Information_raw data by analysis”). ${ }^{2}$ Date associée à PO 110c, un 899 individu trouvé en étroite relation avec PO 110a-b.

900 


\begin{tabular}{|c|c|c|c|c|c|c|c|c|c|c|c|}
\hline \multirow[b]{2}{*}{ Males } & \multicolumn{3}{|c|}{ LUP } & \multicolumn{3}{|c|}{ SMP } & \multicolumn{3}{|c|}{ IRON } & \multirow{2}{*}{$\begin{array}{c}\text { SMP-LUP } \\
\text { HSD }^{\mathbf{1}}\end{array}$} & \multirow{2}{*}{$\begin{array}{c}\text { SMP-IRON } \\
\text { HSD }\end{array}$} \\
\hline & $\mathbf{n}$ & mean & SD & $\mathbf{n}$ & mean & SD & $\mathbf{n}$ & mean & SD & & \\
\hline $\mathrm{Z}_{\mathrm{p}}$ humerus R & 13 & 52.03 & 7.13 & 15 & 54.41 & 9.71 & 124 & 58.82 & 10.29 & NS & NS \\
\hline Z & 13 & 42.28 & 10.53 & 16 & 48.96 & 7.65 & 122 & 50.80 & 8.72 & NS & NS \\
\hline HUMBA & 14 & 58.61 & 28.03 & 15 & 18.95 & 9.11 & 200 & 24.67 & 14.97 & $\mathrm{p}<0.0001$ & NS \\
\hline $\mathrm{Z}_{\mathrm{p}}$ femur & 18 & 106.24 & 10.53 & 13 & 102.90 & 14.47 & 144 & 101.62 & 15.05 & NS & NS \\
\hline $\mathrm{I}_{\mathrm{x}} / \mathrm{I}_{\mathrm{y}}$ femur & 18 & 1.40 & 0.25 & 13 & 1.30 & 0.17 & 156 & 1.07 & 0.18 & NS & $\mathrm{p}<0.0001$ \\
\hline $\mathrm{Z}_{\mathrm{p}}$ tibia & 16 & 109.41 & 15.78 & 13 & 105.82 & 19.29 & 94 & 102.11 & 16.67 & NS & NS \\
\hline $\mathrm{I}_{\max } / \mathrm{I}_{\min }$ tibia & 16 & 2.85 & 0.64 & 13 & 2.63 & 0.30 & 97 & 2.36 & 0.47 & NS & NS \\
\hline Females & $\mathbf{n}$ & mean & SD & $\mathbf{n}$ & mean & SD & $\mathbf{n}$ & mean & SD & HSD & HSD \\
\hline $\mathrm{Z}_{\mathrm{p}}$ humerus R & 4 & 49.24 & 8.06 & 11 & 45.20 & 4.30 & 53 & 48.69 & 6.92 & NS & NS \\
\hline $\mathrm{Z}_{\mathrm{p}}$ humerus L & 5 & 48.15 & 7.51 & 13 & 46.28 & 5.00 & 52 & 46.71 & 6.11 & NS & NS \\
\hline HUMBA & 4 & 12.53 & 2.81 & 12 & 6.4 & 5.66 & 97 & 13.81 & 10.64 & NS & $\mathrm{p}<0.05$ \\
\hline$Z_{p}$ femur & 7 & 96.75 & 13.39 & 12 & 94.81 & 11.40 & 68 & 93.75 & 13.71 & NS & NS \\
\hline $\mathrm{I}_{\mathrm{x}} / \mathrm{I}_{\mathrm{y}}$ femur & 11 & 1.26 & 0.27 & 12 & 1.15 & 0.17 & 71 & 0.99 & 0.18 & NS & $\mathrm{p}<0.05$ \\
\hline $\mathrm{Z}_{\mathrm{p}}$ tibia & 5 & 101.17 & 8.45 & 13 & 97.31 & 15.75 & 39 & 86.04 & 13.73 & NS & $\mathrm{p}<0.05$ \\
\hline $\mathrm{I}_{\max } / \mathrm{I}_{\min }$ tibia & 6 & 2.14 & 0.27 & 13 & 2.34 & 0.32 & 41 & 2.11 & 0.40 & NS & NS \\
\hline $\begin{array}{l}\text { Sexual } \\
\text { Dimorphism }\end{array}$ & & LUP & & & SMP & & & IRON & & & \\
\hline $\mathrm{Z}_{\mathrm{p}}$ humerus R & & $\mathrm{NS}^{2}$ & & & $\mathrm{p}<0.01$ & & & $\mathrm{p}<0.0001$ & & & \\
\hline $\mathrm{Z}_{\mathrm{p}}$ humerus L & & NS & & & NS & & & $\mathrm{p}<0.01$ & & & \\
\hline HUMBA & & $\mathrm{p}<0.01$ & & & $\mathrm{p}<0.001$ & & & $\mathrm{p}<0.0001$ & & & \\
\hline$Z_{p}$ femur & & $\mathrm{p}<0.1$ & & & NS & & & $\mathrm{p}<0.001$ & & & \\
\hline $\mathrm{I}_{\mathrm{x}} / \mathrm{I}_{\mathrm{y}}$ femur & & NS & & & $\mathrm{p}<0.05$ & & & $\mathrm{p}<0.01$ & & & \\
\hline $\mathrm{Z}_{\mathrm{p}}$ tibia & & NS & & & NS & & & $\mathrm{p}<0.0001$ & & & \\
\hline $\mathrm{I}_{\max } / \mathrm{I}_{\min }$ tibia & & $\mathrm{p}<0.05$ & & & $\mathrm{p}<0.05$ & & & $\mathrm{p}<0.01$ & & & \\
\hline
\end{tabular}


Table 2 - Main CSG properties of the Ligurian Neolithic sample (SMP: Square Mouthed Pottery), and of the comparative samples (LUP: European Late Upper Palaeolithic; IRON: Orientalizing-Archaic Samnites from Abruzzo, Italy), by sex. The raw CSG data per individual are given in Supplementary Information Tables A. R: right; L: left. ${ }^{1}$ Tukey's Honest Significant Difference, post-hoc test of ANOVA among groups (LUP-SMP-IRON) by sex. ${ }^{2}$ T-test between sexes, by period. NS: non-significant.

Table 2 - Principales propriétés géométriques les collections squelettiques néolithiques de Ligurie (SMP: culture des Vases à Bouche carrée) et des échantillons de comparaisons (LUP : fin du Paléolithique supérieur européen ; IRON : Age du Fer des Abruzzes, Italie centrale) suivant le sexe. Les données brutes par individu sont disponibles dans l'annexe Table A. R : droite ; L : gauche. ${ }^{1}$ test des étendues de Tukey, Analyse de variance post-hoc (LUP-SMP-IRON) par sexe. ${ }^{2}$ T-test suivant le sexe, par période. NS: non significatif. 


\begin{tabular}{|c|c|c|c|c|}
\hline & \multicolumn{3}{|c|}{ LE Left } & \multirow{2}{*}{$\begin{array}{c}\text { Fisher Exact test } \\
\text { M vs F } \\
\text { (A vs B+C) }\end{array}$} \\
\hline & A & B & C & \\
\hline Males & $6(8)$ & $3(4)$ & $2(3)$ & NS \\
\hline \multirow[t]{3}{*}{ Females } & 5 & 2 & 1 & \\
\hline & \multicolumn{3}{|c|}{ LE Right } & $\begin{array}{c}\text { Fisher Exact test } \\
\text { M vs F } \\
\text { (A vs B+C) }\end{array}$ \\
\hline & A & B & C & \\
\hline Males & 4 & $4(5)$ & 1 & NS \\
\hline \multirow[t]{2}{*}{ Females } & $4(5)$ & 3 & 2 & \\
\hline & \multicolumn{3}{|c|}{$\begin{array}{c}\text { Fisher Exact test } R \text { vs } L \\
(\text { A vs B+C) }\end{array}$} & \\
\hline Males & \multicolumn{3}{|c|}{ NS } & \\
\hline \multirow[t]{3}{*}{ Females } & \multicolumn{3}{|c|}{ NS } & \\
\hline & \multicolumn{3}{|c|}{ LE Asymmetry } & $\begin{array}{l}\text { Fisher Exact test } \\
\text { (R+L vs NO) }\end{array}$ \\
\hline & $\mathbf{L}$ & $\mathbf{R}$ & NO & \\
\hline Males & 0 & 0 & 6 & NS \\
\hline Females & 0 & 1 & 6 & \\
\hline
\end{tabular}

Table 3 - Number of individuals showing entheseal changes (ECs) in the lateral epicondyle (common extensor origin) of the humerus in the Ligurian Neolithic sample, by sex. Numbers and p-values outside of parentheses refer to the SMP sample, numbers and p-values inside the parentheses refer to the pooled Neolithic sample. LE: lateral epicondyle. Scores: A, no change; B, minor changes; C, major changes. L: left; R: right; NO: no asymmetry; M: males; F: females.

Table 3 - Nombre d'individus présentant un changement enthésique (ECs) au niveau de l'épicondyle latéral (origine commune des extenseurs) de l'humérus dans l'échantillon néolithique de Ligurie, suivant le sexe. Les nombres et valeurs p. à l'extérieur des parenthèses font référence à l'échantillon SMP, celles entre parenthèses font référence à l'échantillon total. LE: épicondyle latéral. Scores: A, pas de changement; B, changements mineurs ; C, changements majeurs. L: gauche; R: droit; NO: pas d'asymétrie; M: hommes; F: femmes. 


\begin{tabular}{|c|c|c|c|c|}
\hline & \multicolumn{3}{|c|}{ CFT Left } & \multirow{2}{*}{$\begin{array}{c}\text { Fisher Exact test } \\
\text { M vs F } \\
(\text { A vs B+C) }\end{array}$} \\
\hline & $\mathbf{A}$ & B & C & \\
\hline Males & $7(9)$ & 3 & 0 & NS \\
\hline \multirow[t]{3}{*}{ Females } & $6(7)$ & 2 & 0 & \\
\hline & \multicolumn{3}{|c|}{ CFT Right } & $\begin{array}{c}\text { Fisher Exact test } \\
\text { M vs F } \\
\text { (A vs B+C) }\end{array}$ \\
\hline & A & B & C & \\
\hline Males & 4 & 6 & 0 & NS \\
\hline \multirow[t]{2}{*}{ Females } & $5(6)$ & 4 & 0 & \\
\hline & \multicolumn{3}{|c|}{$\begin{array}{c}\text { Fisher Exact test } R \text { vs } L \\
(A \text { vs B }+C)\end{array}$} & \\
\hline Males & \multicolumn{3}{|c|}{ NS } & \\
\hline \multirow[t]{3}{*}{ Females } & \multicolumn{3}{|c|}{ NS } & \\
\hline & \multicolumn{3}{|c|}{ CFT ASYMM } & $\begin{array}{c}\text { Fisher Exact test } \\
\text { M vs F } \\
\text { (R+L vs NO) }\end{array}$ \\
\hline & $\mathbf{L}$ & $\mathbf{R}$ & NO & \\
\hline Males & 0 & 4 & 2 & $\mathrm{p}<0.1(\mathrm{p}<0.05)$ \\
\hline Females & 0 & 1 & $6(7)$ & \\
\hline
\end{tabular}

Table 4 - Number of individuals showing entheseal changes (ECs) in the area of attachment of the common flexor tendon (CFT; medial epicondyle of the humerus) in the Ligurian Neolithic sample, by sex. Numbers and p-values not in parentheses refer to the SMP sample, numbers and p-values in parentheses refer to the pooled Neolithic sample. Scores: A, no change; B, minor changes; C, major changes. L: left; R: right; NO: no asymmetry; M: males; F: females.

Table 4 - Nombre d'individus présentant un changement enthésique (ECs) au niveau de l'insertion commune des fléchisseurs de l'humérus (CFT) dans l'échantillon néolithique de Ligurie, suivant le sexe. Les nombres et valeurs p. à l'extérieur des parenthèses font référence à l'échantillon SMP, celles entre parenthèses font référence à l'échantillon total. Scores: $\mathrm{A}$, pas de changement; $\mathrm{B}$, changements mineurs ; C, changements majeurs. L: gauche; R: droit; NO: pas d’asymétrie; M: hommes; F: femmes. 


\begin{tabular}{|c|c|c|c|c|}
\hline & \multicolumn{2}{|c|}{ UCL_Left } & \multirow[t]{2}{*}{$\begin{array}{c}\text { Fisher Exact } \\
\text { test } M \text { vs } F\end{array}$} & \\
\hline & A & $\mathbf{P}$ & & \\
\hline Males & $11(16)$ & 1 & $\mathrm{p}=\mathrm{NS}$ & \\
\hline \multirow[t]{3}{*}{ Females } & $11(12)$ & 1 & & \\
\hline & \multicolumn{2}{|c|}{ UCL_Right } & $\begin{array}{l}\text { Fisher Exact } \\
\text { test M vs F }\end{array}$ & \\
\hline & A & $\mathbf{P}$ & & \\
\hline Males & $3(6)$ & 7 & $\begin{array}{l}\mathrm{p}<0.05 \\
(\mathrm{p}<0.1)\end{array}$ & \\
\hline \multirow[t]{2}{*}{ Females } & $10(11)$ & 2 & & \\
\hline & \multicolumn{2}{|c|}{$\begin{array}{l}\text { Fisher Exact } \\
\text { test R vs L }\end{array}$} & & \\
\hline Males & \multicolumn{2}{|c|}{$\mathrm{p}<0.01(\mathrm{p}<0.01)$} & & \\
\hline \multirow[t]{3}{*}{ Females } & \multicolumn{2}{|c|}{ NS } & & \\
\hline & \multicolumn{2}{|c|}{ UCL ASYMM } & & \\
\hline & $\mathbf{L}$ & $\mathbf{R}$ & NO & $\begin{array}{c}\text { Fisher Exact test } M \text { vs } F \\
(R+L \text { vs NO) }\end{array}$ \\
\hline Males & 0 & 6 & $2(5)$ & \multirow{2}{*}{$\begin{array}{c}\mathrm{p}<0.01 \\
(\mathrm{p}<0.05)\end{array}$} \\
\hline Females & 0 & 1 & $10(11)$ & \\
\hline
\end{tabular}

Table 5 - Number of individuals showing erosions/cavitations/geodes and/or fissures/well-defined pits $($ ECG $+F P)$ in the anterior band of the ulnar collateral ligament in the Ligurian Neolithic sample, by sex. Numbers and p-values not in parentheses refer to the SMP sample, numbers and p-values in parentheses refer to the pooled Neolithic sample. A: no change; P: trait is present; L: left; R: right; M: males; F: females.

Table 5 - Nombre d'individus présentant une érosion/cavité/ géodes et/ou une fissure/dépression(ECG+FP) au niveau de l’insertion du fascia antérieur du ligament collatéral médial dans l'échantillon néolithique de Ligurie, suivant le sexe. Les nombres et valeurs p. à l'extérieur des parenthèses font référence à l'échantillon SMP, celles entre parenthèses font référence à l'échantillon total. Scores: A, pas de changement; P, changements present. L: gauche; R: droit; NO: pas d'asymétrie; M: hommes; F: femmes. 


\begin{tabular}{|c|c|c|c|c|}
\hline & \multicolumn{2}{|c|}{$\begin{array}{c}\text { ME any change } \\
\text { Left }\end{array}$} & \multirow[t]{2}{*}{$\begin{array}{c}\text { Fisher Exact } \\
\text { test M vs F }\end{array}$} & \\
\hline & A & $\mathbf{P}$ & & \\
\hline Males & $7(9)$ & 3 & NS & \\
\hline \multirow[t]{3}{*}{ Females } & $4(5)$ & 2 & & \\
\hline & \multicolumn{2}{|c|}{$\begin{array}{l}\text { ME any change } \\
\text { Right }\end{array}$} & $\begin{array}{c}\text { Fisher Exact } \\
\text { test M vs F }\end{array}$ & \\
\hline & A & $\mathbf{P}$ & & \\
\hline Males & $1(2)$ & 8 & NS & \\
\hline \multirow[t]{2}{*}{ Females } & $3(4)$ & 6 & & \\
\hline & \multicolumn{3}{|c|}{$\begin{array}{c}\text { Fisher Exact } \\
\text { test R vs L }\end{array}$} & \\
\hline Males & \multicolumn{3}{|c|}{$\mathrm{p}<0.05(\mathrm{p}<0.05)$} & \\
\hline \multirow[t]{3}{*}{ Females } & \multicolumn{3}{|c|}{ NS } & \\
\hline & \multicolumn{3}{|c|}{ ME any change ASYMM } & \\
\hline & $\mathbf{L}$ & $\mathbf{R}$ & NO & $\begin{array}{c}\text { Fisher Exact test } M \text { vs } F \\
(R+L \text { vs NO) }\end{array}$ \\
\hline Males & 0 & 5 & 1 & \multirow{2}{*}{ NS } \\
\hline Females & 0 & 2 & $4(5)$ & \\
\hline
\end{tabular}

Table 6 - Number of individuals showing any entheseal change in the common flexor attachment site (scored B or C in Table 4) or in the anterior band of the ulnar collateral ligament (ECG or FP) in the Ligurian Neolithic sample, by sex. The table includes data exclusively from individuals for which both areas could be examined. Numbers and p-values not in parentheses refer to the SMP sample, numbers and p-values in parentheses refer to the pooled Neolithic sample. L: left; R: right; M: males; F: females.

Table 6 - Nombre d'individus présentant un changement enthésique au niveau de l'origine commune des flechisseurs (score B ou C dans le tableau 4) ou au niveau de l'insertion du fascia antérieur du ligament collatéral médial (ECG ou FP) dans l'échantillon néolithique de Ligurie, suivant le sexe.Le tableau inclus uniquement les individus pour lesquels les deux zones ont pu être examinées. Les nombres et valeurs p. à l'extérieur des parenthèses font référence à l'échantillon SMP, celles entre parenthèses font référence à l'échantillon total. L: gauche; R: droit; NO: pas d'asymétrie; M: hommes; F: femmes. 


\begin{tabular}{|c|c|c|c|c|}
\hline & \multicolumn{2}{|c|}{$\begin{array}{c}\text { ME any change } \\
\text { Left }\end{array}$} & \multirow[t]{2}{*}{$\begin{array}{l}\text { Fisher Exact } \\
\text { test M vs F }\end{array}$} & \\
\hline & A & $\mathbf{P}$ & & \\
\hline Males & $9(14)$ & 3 & NS & \\
\hline \multirow[t]{3}{*}{ Females } & $11(12)$ & 3 & & \\
\hline & \multicolumn{2}{|c|}{$\begin{array}{c}\text { ME any change } \\
\text { Right }\end{array}$} & $\begin{array}{l}\text { Fisher Exact } \\
\text { test M vs F }\end{array}$ & \\
\hline & A & $\mathbf{P}$ & & \\
\hline Males & $2(5)$ & 10 & NS & \\
\hline \multirow[t]{2}{*}{ Females } & $6(7)$ & 6 & & \\
\hline & \multicolumn{3}{|c|}{$\begin{array}{l}\text { Fisher Exact } \\
\text { test R vs L }\end{array}$} & \\
\hline Males & \multicolumn{3}{|c|}{$\mathrm{p}<0.05(\mathrm{p}<0.05)$} & \\
\hline \multirow[t]{3}{*}{ Females } & \multicolumn{3}{|c|}{ NS } & \\
\hline & \multicolumn{3}{|c|}{ ME any change ASYMM } & \\
\hline & $\mathbf{L}$ & $\mathbf{R}$ & NO & $\begin{array}{c}\text { Fisher Exact test } M \text { vs } \\
\text { F } \\
(\mathrm{R}+\mathbf{L} \text { vs NO) }\end{array}$ \\
\hline Males & 0 & 7 & $1(4)$ & \multirow{2}{*}{$\mathrm{p}<0.05(\mathrm{p}<0.1)$} \\
\hline Females & 0 & 3 & $9(10)$ & \\
\hline
\end{tabular}

Table 7 - Number of individuals showing any entheseal change in the common flexor attachment site (scored B or C in Table 4) or in the anterior band of the ulnar collateral ligament (ECG or FP) in the Ligurian Neolithic sample, by sex. The table include data from all individuals for which at least one area could be examined. Numbers and p-values not in parentheses refer to the SMP sample, numbers and pvalues in parentheses refer to the pooled Neolithic sample. L: left; R: right; M: males; F: females.

Table 7 - Nombre d'individus présentant un changement enthésique au niveau de l'origine commune des flechisseurs (score B ou C dans le tableau 4) ou au niveau de l'insertion du fascia antérieur du ligament collatéral médial (ECG ou FP) dans l'échantillon néolithique de Ligurie, suivant le sexe.Le tableau inclus tous les individus pour lesquels au moins une zone a pu être examinée. Les nombres et valeurs p. à l'extérieur des parenthèses font référence à l'échantillon SMP, celles entre parenthèses font référence à l'échantillon total. L: gauche; R: droit; NO: pas d'asymétrie; M: hommes; F: femmes. 


\section{Figures}
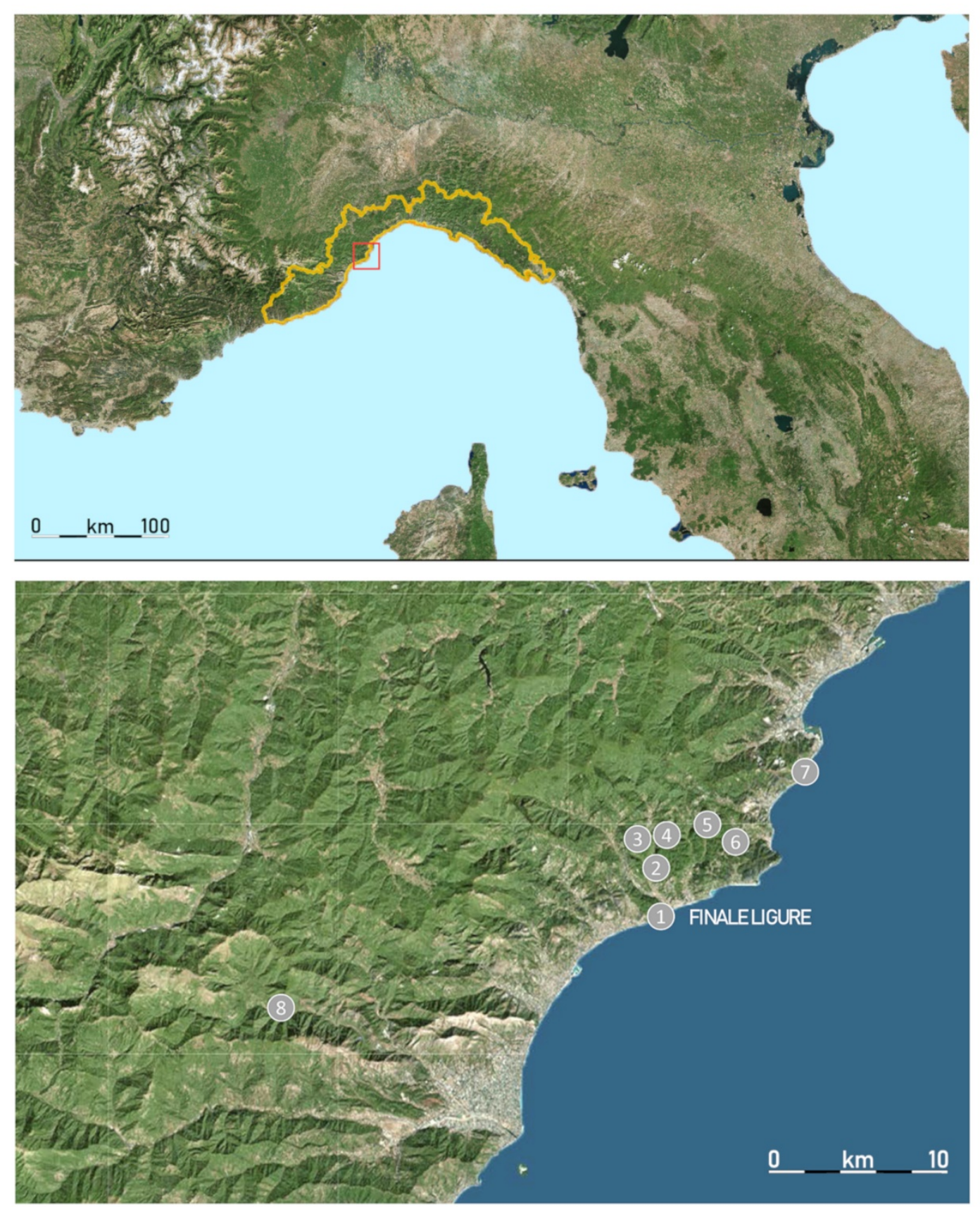

Figure 1 - Geographical location of the Finalese area in Liguria (northwestern Italy), and location of the cave sites included in this study: 1) Arene Candide; 2) La Matta; 3) Pollera; 4) Arma dell’Aquila; 5) Pipistrelli; 6) Pian del Ciliegio; 7) Bergeggi; 8) Nasino.

Figure 1 - Localisations de la zone de Finale Ligure en Ligurie (Nord-Ouest de l'Italie) et des sites inclus dans cette étude : 1) Arene Candide; 2) La Matta; 3) Pollera; 4) Arma dell’Aquila; 5) Pipistrelli; 6) Pian del Ciliegio; 7) Bergeggi; 8) Nasino. 


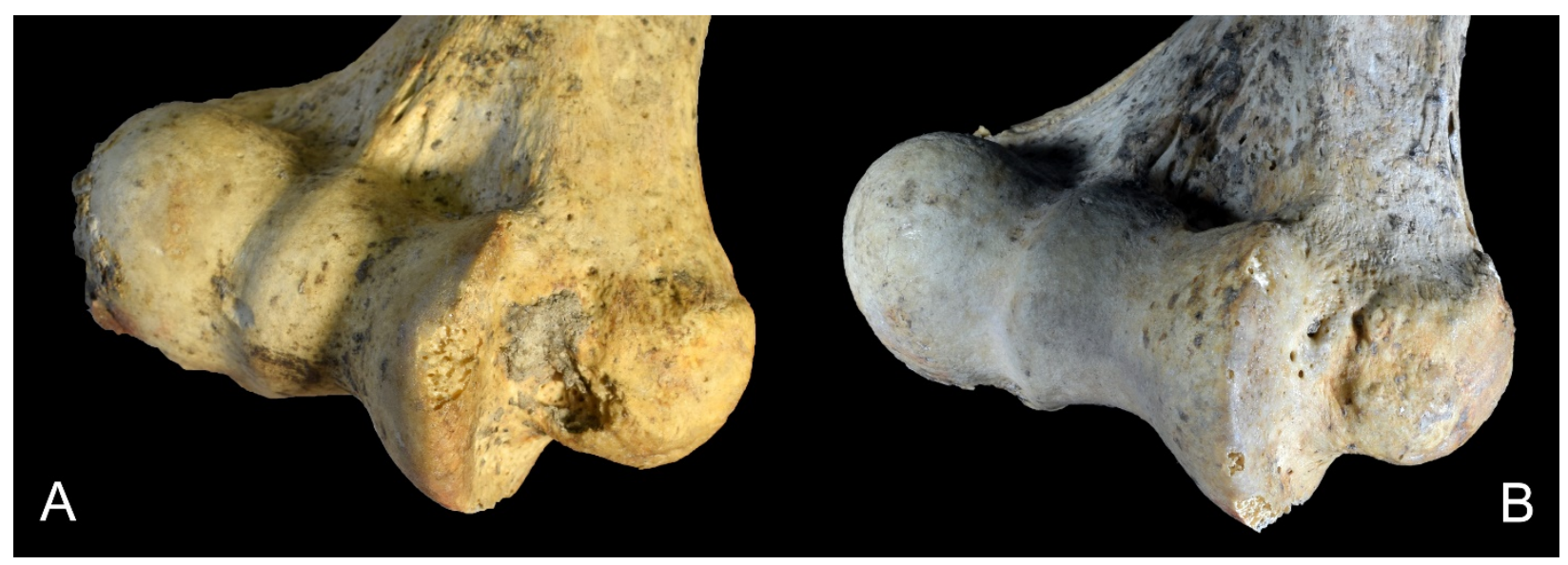

Figure 2 - Bony defects at the medial epicondyle, in the site of attachment of the anterior fascia of the ulnar collateral ligament. A) Individual Arene Candide 7 PE, despite the concretion obscuring part of the site, clearly shows a cavitation of the cortical surface and the formation of a geode, and was scored 1 for ECG. B) Individual Pollera 30, showing a fissure and well-defined pits in the area, but no interruption of the cortical surface. Scored 0 for ECG, 1 for ECG+FP.

Figure 2 - Défauts osseux au niveau de l'épicondyle médial, dans la zone d’insertion dufascia antérieur du ligament collatéral médial. A) Individu Arene Candide 7 PE, qui en dépit de la concrétion qui recouvre la zone montre clairement un relief négatif au niveau de la surface et la formation d'une géode, avec un score 1 pour ECG. B) Individu Pollera 30, qui présente une fissure et des dépressions clairement visibles, mais sans rupture de la surface. Scoré 0 pour ECG, 1 pour ECG+FP. 

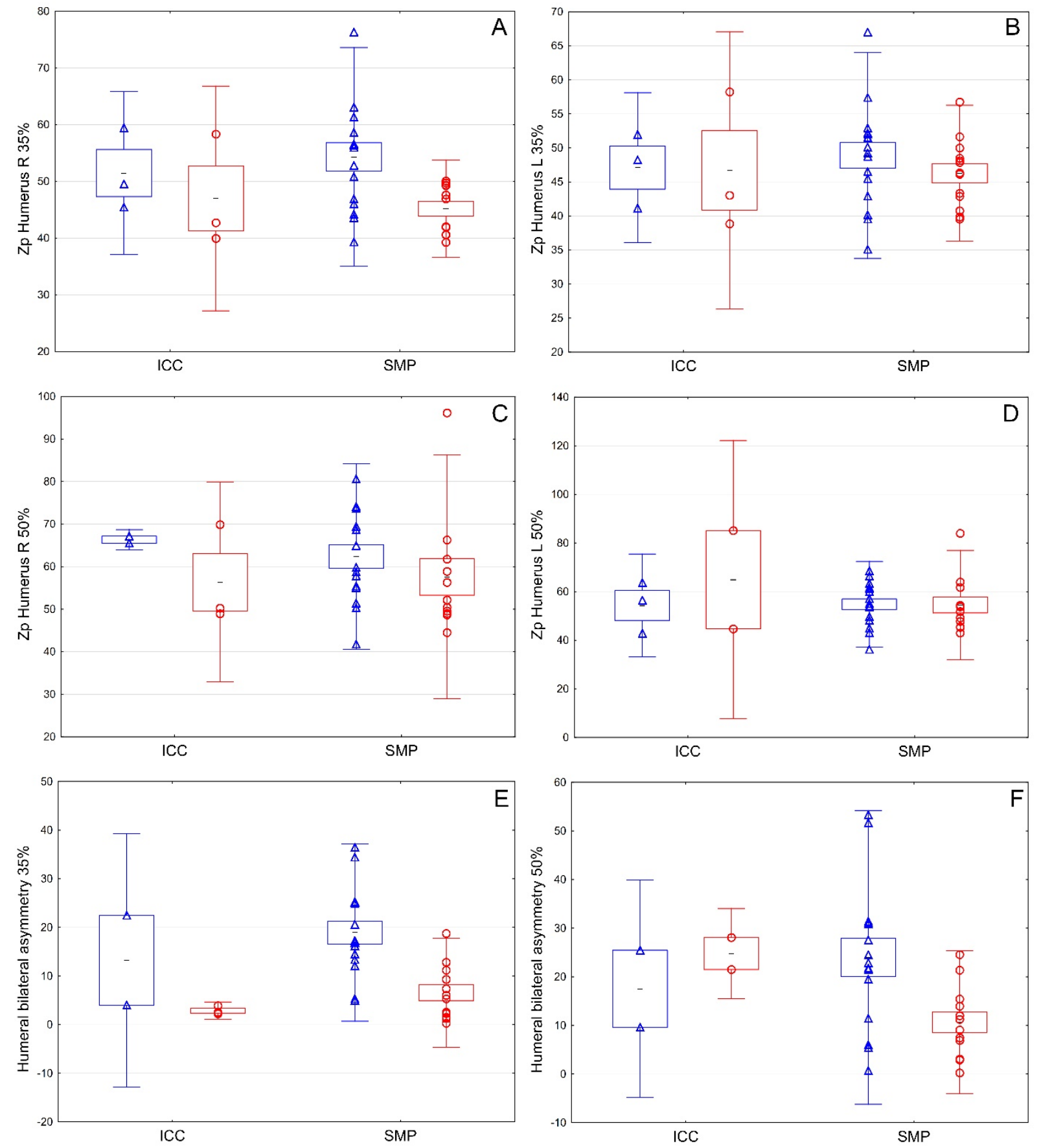

Figure 3 - Boxplots showing the main cross-sectional geometric (CSG) properties of the upper limb in the Ligurian Neolithic skeletal series, subdivided by chronological phase. The boxes indicate the standard error, the whiskers indicate two standard deviations from the mean. ICC: Impresso-Cardial Complex (c. 5800-5000 BCE); SMP: Square Mouthed Pottery (c. 5000-4300 BCE). F: females (circles); M: males (triangles); U: undetermined sex (squares). A) Mid-distal size-standardized right humeral robusticity; B) mid-distal size-standardized left humeral robusticity; C) midshaft size-standardized right humeral robusticity; D) midshaft size- 
standardized left humeral robusticity; E) mid-distal humeral asymmetry in torsional rigidity (J) expressed as percentage; F) midshaft humeral asymmetry in torsional rigidity $(\mathrm{J})$ expressed as percentage. All raw data are given in Supplementary Information Tables A.

Figure 3 - Boites à moustaches montrant les principales propriétés géométriquesdes sections transverses (CSG) du membre supérieur pour les collections squelettiques néolithiques de Ligurie, par phase chronologique. La boite indique l'erreur standard et les moustaches montrent deux écart-types. ICC: complexe impresso-cardial (c. 5800-5000 BCE); SMP: culture des Vases à Bouche carrée (c. 5000-4300 BCE). F: femmes (cercles); M: hommes (triangles); U: sexes indéterminés (carrés). A) Robustesse humérale droite à mi distale de diaphyse, standardisée sur la taille; B) Robustesse humérale gauche à mi distale de diaphyse, standardisée sur la taille ;C) Robustesse humérale droite à mi diaphyse, standardisée sur la taille ; D)Robustesse humérale gauche à mi diaphyse, standardisée sur la taille ; E) Asymétrie humérale du moment polaire de l'aire (J) à mi distal de diaphyse exprimée en pourcentage ; F) Asymétrie humérale du moment polaire de l'aire (J) à mi diaphyse exprimée en pourcentage. Toutes les données brutes sont disponibles dans l'annexe Table A. 

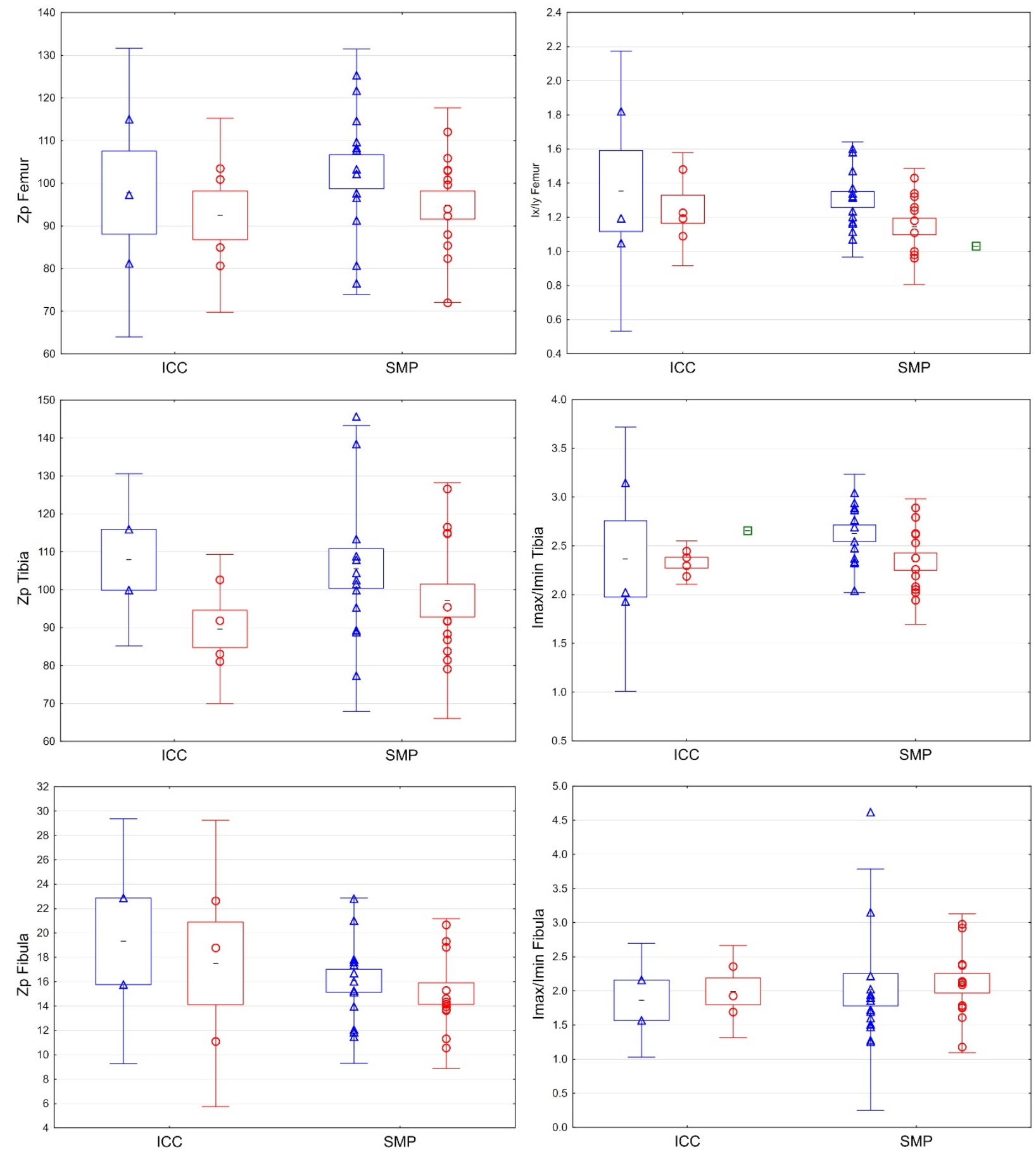

Figure 4 - Boxplots showing the main cross-sectional geometric (CSG) properties of the lower limb in the Ligurian Neolithic skeletal series, subdivided by chronological phase. The boxes indicate the standard error, the whiskers indicate two standard deviations from the mean. ICC: Impresso-Cardial Complex (c. 5800-5000 BCE); SMP: Square Mouthed Pottery (c. 5000-4300 BCE). F: females (circles); M: males (triangles); U: undetermined sex (squares). A) Midshaft size-standardized femoral robusticity; B) mid-distal femoral shape index $\mathrm{I}_{\mathrm{x}} / \mathrm{I}_{\mathrm{y}}$; C) midshaft size- 
standardized tibial robusticity; D) midshaft tibial shape index $\mathrm{I}_{\max } / \mathrm{I}_{\min }$; E) midshaft sizestandardized fibular robusticity; F) midshaft fibular shape index $\mathrm{I}_{\max } / \mathrm{I}_{\min }$. All raw data are given in Supplementary Information Tables A.

Figure 4 - Boites à moustaches montrant les principales propriétés géométriques des sections transverses (CSG) du membre inférieur pour les collections squelettiques néolithiques de Ligurie, par phase chronologique. La boite indique l'erreur standard et les moustaches montrent deux écart-types. ICC: complexe impresso-cardial (c. 5800-5000 BCE); SMP: culture des Vases à Bouche carrée (c. 5000-4300 BCE). F: femmes (cercles); M: hommes (triangles); U: sexes indéterminés (carrés).A) Robustesse fémorale à mi diaphyse, standardisée sur la taille ; B) Indice de forme $\left(\mathrm{I}_{\mathrm{x}} / \mathrm{I}_{\mathrm{y}}\right)$ du fémur à mi distal de diaphyse ; $\left.\mathrm{C}\right)$ Robustesse tibiale à mi diaphyse, standardisée sur la taille ; D) Indice de forme $\left(\mathrm{I}_{\max } / \mathrm{I}_{\min }\right)$ du tibia à mi diaphyse ; E) Robustesse fibulaire à mi diaphyse, standardisée sur la taille ; F) Indice de forme $\left(I_{\max } / I_{\min }\right)$ de la fibula à mi diaphyse. Toutes les données brutes sont disponibles dans l’annexe Table A.
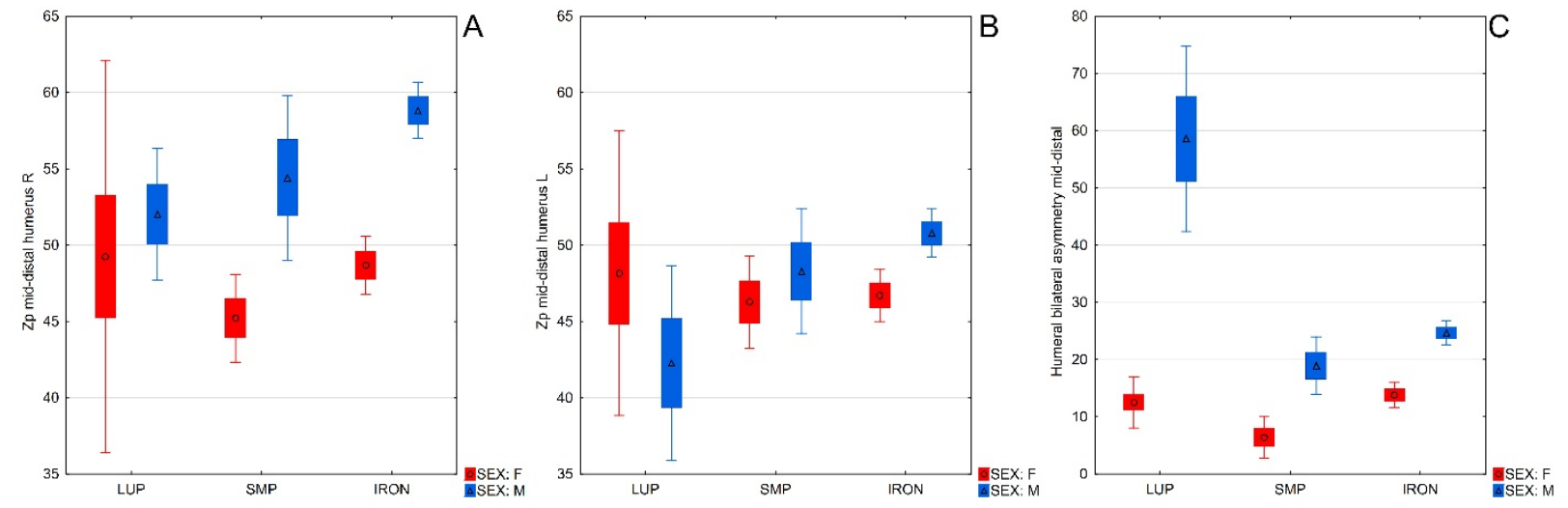

Figure 5 - Boxplots showing diachronic changes in humeral cross-sectional geometric (CSG) properties from the European Late Upper Palaeolithic (LUP), through the Square Mouthed Pottery Neolithic of Liguria (SMP), to the Orientalizing-Archaic Iron Age of Abruzzo, central Italy (IRON), by sex. The boxes indicate the standard error, the whiskers indicate $1.96 \times \mathrm{SE}$. A) Mid-distal size-standardized right humeral robusticity; B) mid-distal size-standardized left humeral robusticity; C) mid-distal humeral asymmetry in torsional rigidity.

Figure 5 - Boites à moustaches montrant les variations diachroniques des propriétés géométriques des sections transverses (CSG) de l'humérus suivant le sexe. LUP : fin Paléolithique supérieur européen ; SMP : culture des Vases à Bouche carrée ; IRON : Age du Fer des Abruzzes, Italie centrale. La boite indique l'erreur standard et les moustaches montrent 1,96 * l'erreur standard. A) Robustesse humérale droite à mi distale de diaphyse, standardisée sur la taille; B) Robustesse humérale gauche à mi distale de diaphyse, standardisée sur la taille ;C) Asymétrie humérale du moment polaire de l'aire (J) à mi distal de diaphyse. 

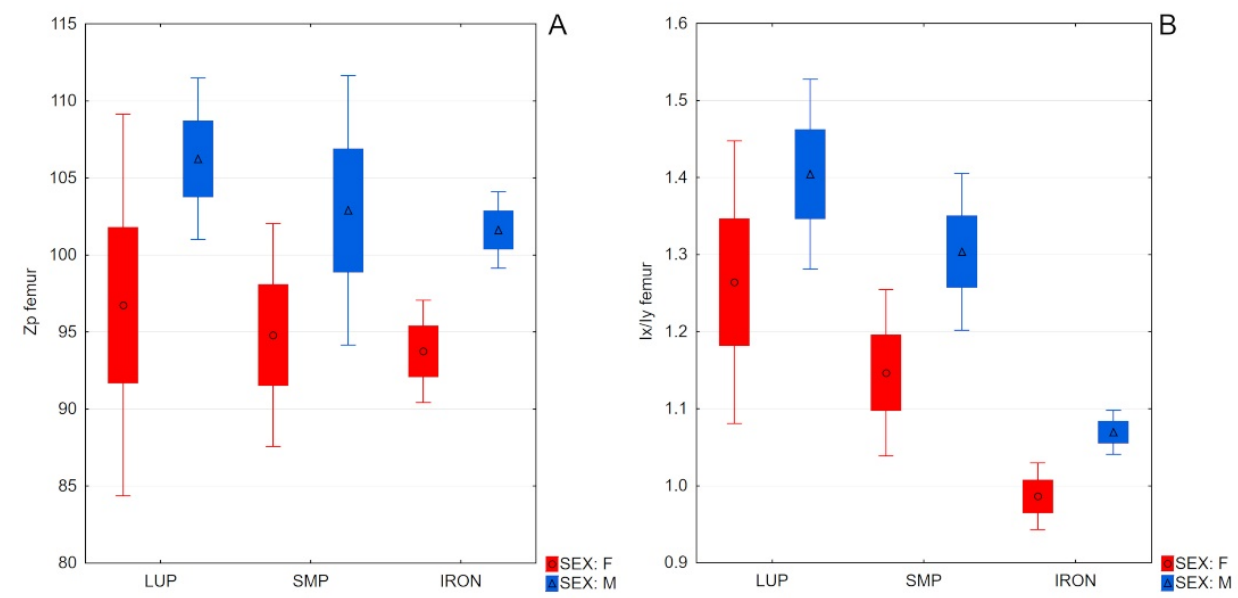

Figure 6 - Boxplots showing diachronic changes in femoral cross-sectional geometric (CSG) properties from the European Late Upper Palaeolithic (LUP), through the Square Mouthed Pottery Neolithic of Liguria (SMP), to the Orientalizing-Archaic Iron Age of Abruzzo, central Italy (IRON), by sex. The boxes indicate the standard error, the whiskers indicate $1.96 \times \mathrm{SE}$. A) Midshaft size-standardized femoral robusticity; B) mid-distal femoral shape index $\mathrm{I}_{\mathrm{x}} / \mathrm{I}_{\mathrm{y}}$.

Figure 6 - Boites à moustaches montrant les variations diachroniques des propriétés géométriques des sections transverses (CSG) du fémur suivant le sexe. LUP : fin du Paléolithique supérieur européen ; SMP :culture des Vases à Bouche carrée ; IRON : Age du Fer des Abruzzes, Italie centrale. La boite indique l'erreur standard et les moustaches montrent 1,96 * l'erreur standard. A) Robustesse fémorale à mi diaphyse, standardisée sur la taille ;B) Indice de forme $\left(\mathrm{I}_{\mathrm{x}} / \mathrm{I}_{\mathrm{y}}\right)$ du fémur à mi distal de diaphyse.
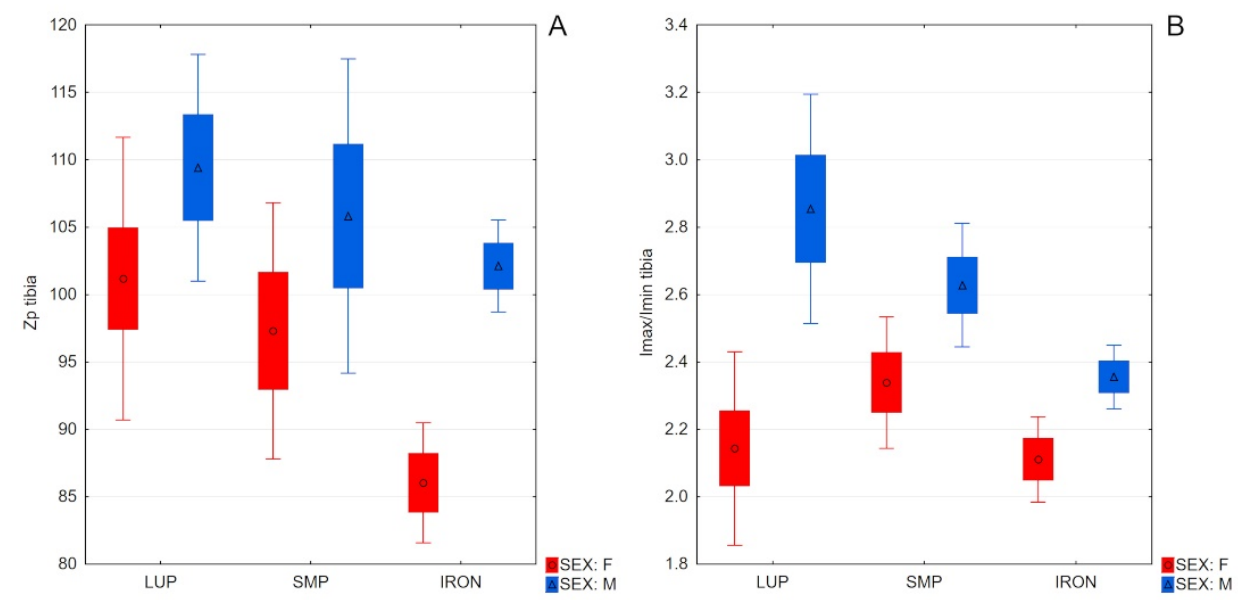

Figure 7 - Boxplots showing diachronic changes in tibial cross-sectional geometric (CSG) properties from the European Late Upper Palaeolithic (LUP), through the Square Mouthed Pottery Neolithic of Liguria (SMP), to the Orientalizing-Archaic Iron Age of Abruzzo, central 
Italy (IRON), by sex. The boxes indicate the standard error, the whiskers indicate $1.96 \times \mathrm{SE}$. A) Midshaft size-standardized tibial robusticity; B) midshaft tibial shape index $I_{\max } / I_{\min }$.

Figure 7 - Boites à moustaches montrant les variations diachroniques des propriétés géométriques des sections transverses(CSG) du tibia suivant le sexe. LUP : fin du Paléolithique supérieur européen ; SMP :culture des Vases à Bouche carrée ; IRON : Age du Fer des Abruzzes, Italie centrale. La boite indique l'erreur standard et les moustaches montrent 1,96 * l'erreur standard. A) Robustesse tibiale à mi diaphyse, standardisée sur la taille ;B) Indice de forme $\left(I_{\max } / I_{\min }\right)$ du tibia à mi de diaphyse. 

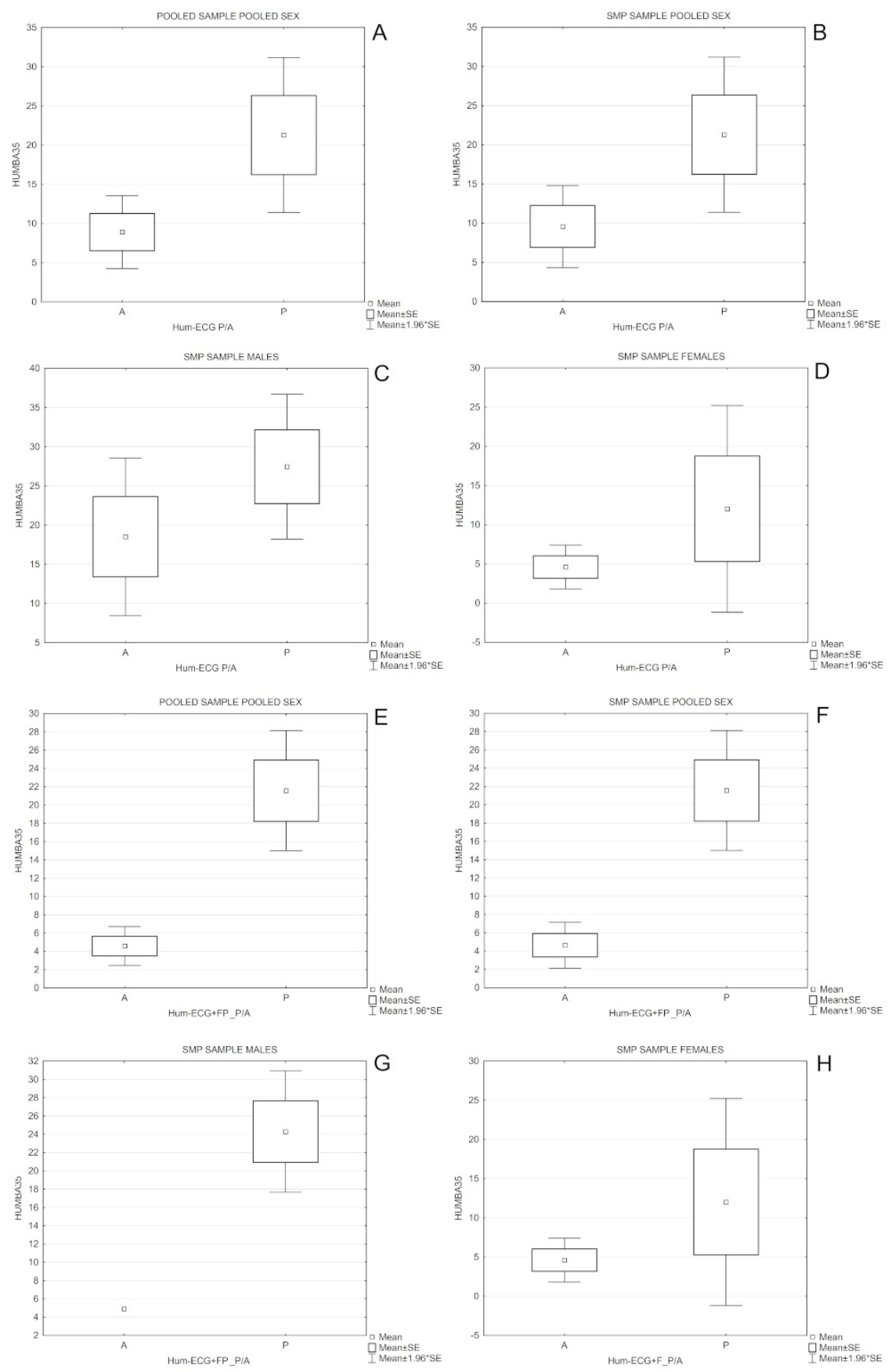

Figure 8 - Boxplots showing differences in mid-distal humeral bilateral asymmetry in torsional rigidity in subsamples based on the presence/absence of erosions/cavitations/geodes (ECG) or ECG plus fissures/well-defined pits at the medial epicondyle, in the site of attachment of the anterior fascia of the ulnar collateral ligament. The boxes indicate the standard error, the whiskers indicate $1.96 \times$ SE. A) ECG presence/absence, pooled Ligurian Neolithic sample, pooled sexes; B) ECG presence/absence, SMP sample, pooled sexes; C) ECG presence/absence, SMP sample, males; D) ECG presence/absence, SMP sample, females; E) ECG+FP presence/absence, pooled Ligurian Neolithic sample, pooled sexes; F) ECG+FP 
presence/absence, SMP sample, pooled sexes; G) ECG+FP presence/absence, SMP sample, males; H) ECG+FP presence/absence, SMP sample, females.

Figure 8 - Boites à moustaches montrant les différences d'asymétrie humérale du moment polaire de l'aire (J) à mi distal de diaphyse suivant la présence ou l'absence

d'érosions/cavité/géodes (ECG) ou d'ECG associées à des fissures ou des dépressions au niveau de l'épicondyle médial, dans la zone d'insertion dufascia antérieur du ligament collatéral médial. La boite indique l'erreur standard et les moustaches montrent 1,96 * l'erreur standard. A) présence ou absence d'ECG, échantillons néolithiques et sexes confondus ; B) présence ou absence d'ECG pour l'échantillon SMP, sexes confondus ; C) présence ou absence d'ECG pour l'échantillon SMP, hommes ; D) présence ou absence d'ECG pour l'échantillon SMP, femmes ; E) présence ou absence d'ECG+FP, échantillons néolithiques et sexes confondus ; F) présence ou absence d'ECG+FP pour l'échantillon SMP, sexes confondus ; G) présence ou absence d'ECG+FP pour l'échantillon SMP, hommes ; H) présence ou absence d'ECG+FP pour l'échantillon SMP, femmes.
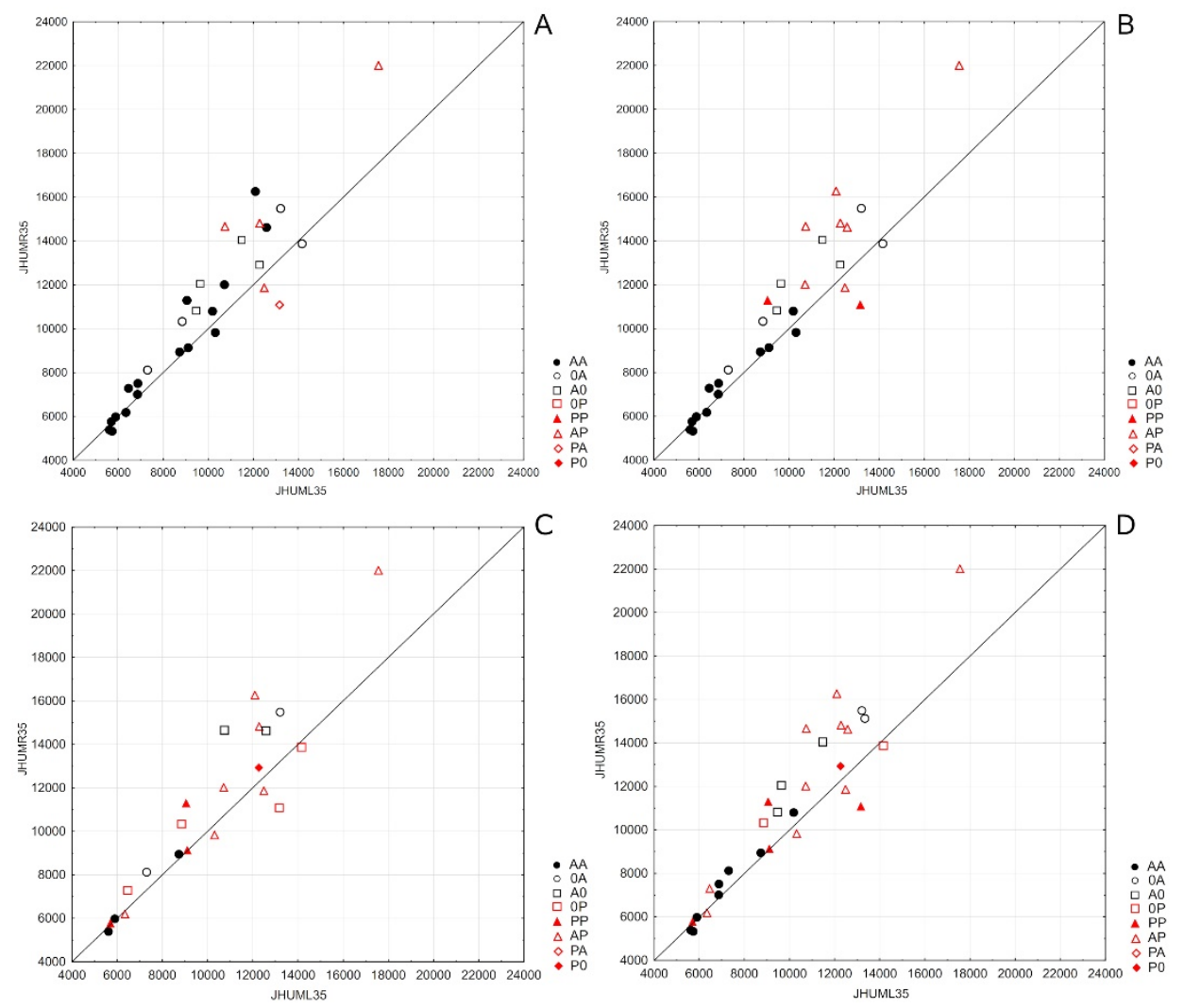

Figure 9 - Scatterplot of right humeral torsional rigidity $(\mathrm{J})$ on left humeral torsional rigidity of the Ligurian Neolithic skeletal series, categorized on the basis of presence/absence and side of occurrence of A) ECG; B) ECG+FP; C) any change in the ME (UCL or CFT), considering only individuals for which both regions could be scored; D) any change in the ME (UCL or CFT), 
considering also individuals for which only one region could be scored (see methods). The solid line indicates isometry. AA (black solid circles): left: trait absent, right: trait absent; 0A (black circles) left: site not observable, right: trait absent; A0 (black squares) left: trait absent, right: site not observable; OP (red squares) left: not observable, right: trait present; PP (solid red triangles): left: trait present, right: trait present; AP (red triangles): left: trait absent, right: trait present; PA (red diamonds) left: trait present, right: trait absent; P0 (solid red diamonds) left: trait present, right: not observable.

Figure 9 - Diagramme bivarié du moment polaire de l’aire (J) à mi distal de diaphyse du côté gauche par rapport au côté droit pour les collections néolithiques, catégorisées sur la base de la présence ou de l'absence et de la latéralité de A) ECG ; B) ECG+FP ; C) tous les changements au niveau du ME (UCL ou CFT) en ne considérant seulement que les individus pour lesquels les deux zones peuvent être enregistrées ; D) tous les changements au niveau du ME (UCL ou CFT) en considérant tous les individus (voir la section méthode). La ligne indique l’isométrie. AA (cercles noirs pleins) : trait absent à gauche, trait absent à droite ; 0A (cercles noirs) : trait non observable à gauche, absent à droite ; A0 (carrés noirs) : trait absent à gauche, non observable à droite ; OP (carrés rouges) : : trait non observable à gauche, présent à droite ; PP (triangles rouges pleins) : trait présent à gauche ; trait présent à droite ; AP (triangles rouges) : trait absent à gauche ; présent à droite ; PA (losanges rouges) : trait présent à gauche ; absent à droite ; P0 (losanges rouges pleins) : trait présent à gauche et non observable à droite.

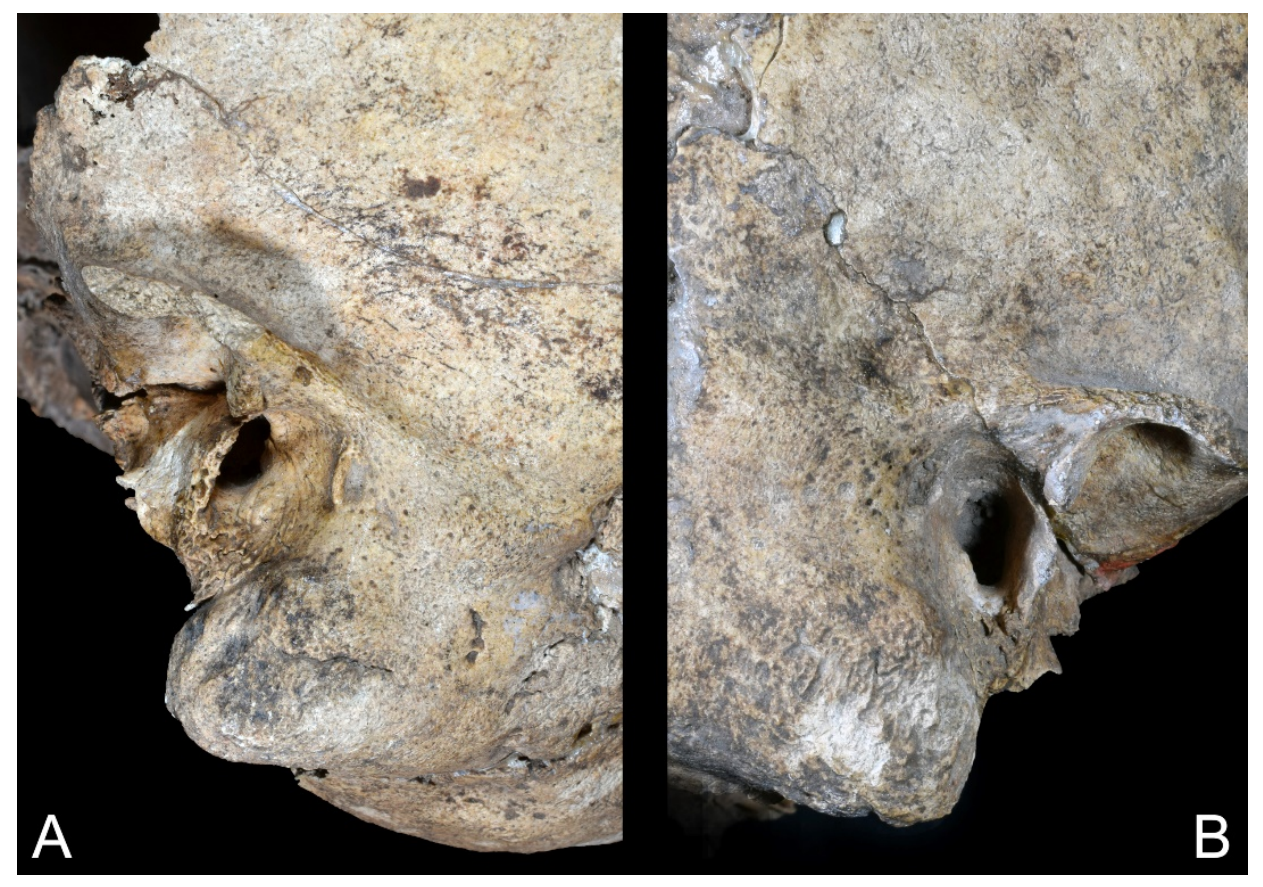

Figure 10 - Slight (score 1) bilateral external auditory canal exostosis (EAE) in the individual $\mathrm{n}^{\circ} 1$ from Arma dell’Aquila, excavations Richard. A: left side; B: right side.

Figure 10. Exostose du canal auditif externe bilaterale légère (score 1 ) chez l'individu $\mathrm{n}^{\circ} 1$ d’Arma dell’ Aquila, fouilles Richard. A : côté gauche ; B : côté droit. 